\title{
The Effects of Iron Rust on the Ageing of Woods and Their Derived Pulp Paper
}

\author{
Wael A. A. Abo Elgat ${ }^{1}\left(\mathbb{D}\right.$, Ayman S. Taha $^{2} \mathbb{D}$, Mohamed Z. M. Salem ${ }^{3, * \mathbb{D}}$, Yahia G. D. Fares ${ }^{4}$, Martin Böhm $^{5} \mathbb{D}$, \\ Mourad F. Mohamed ${ }^{6}$, Ramadan A. Nasser ${ }^{3}$ and Vojtěch Pommer ${ }^{5}$ \\ 1 Restoration Department, High Institute of Tourism, Hotel Management and Restoration, Abukir, \\ Alexandria 21526, Egypt; watsat20@yahoo.com \\ 2 Conservation Department, Faculty of Archaeology, Aswan University, Aswan 81528, Egypt; \\ aymansalahtaha82@yahoo.com \\ 3 Forestry and Wood Technology Department, Faculty of Agriculture (EL-Shatby), Alexandria University, \\ Alexandria 21545, Egypt; nasser67@alexu.edu.eg \\ 4 General Laboratory and Research, Misr Edfu Pulp Writing and Printing Paper Co. (MEPPCO), \\ Aswan 81656, Egypt; yahyagml@yahoo.com \\ 5 Department of Materials Engineering and Chemistry, Faculty of Civil Engineering, \\ Czech Technical University in Prague, Thákurova 7, 16629 Prague 6, Czech Republic; \\ martin.bohm@fsv.cvut.cz (M.B.); vojtech.pommer@fsv.cvut.cz (V.P.) \\ 6 Restoration Department, Faculty of Archaeology, Cairo University, Giza 12613, Egypt; msms147@yahoo.com \\ * Correspondence: zidan_forest@yahoo.com
}

check for updates

Citation: Abo Elgat, W.A.A.; Taha, A.S.; Salem, M.Z.M.; Fares, Y.G.D.; Böhm, M.; Mohamed, M.F.; Nasser, R.A.; Pommer, V. The Effects of Iron Rust on the Ageing of Woods and Their Derived Pulp Paper. Polymers 2021, 13, 3483. https://doi.org/ $10.3390 /$ polym 13203483

Academic Editor: Abdel-Hamid I. Mourad

Received: 19 September 2021

Accepted: 8 October 2021

Published: 11 October 2021

Publisher's Note: MDPI stays neutral with regard to jurisdictional claims in published maps and institutional affiliations.

Copyright: (c) 2021 by the authors. Licensee MDPI, Basel, Switzerland. This article is an open access article distributed under the terms and conditions of the Creative Commons Attribution (CC BY) license (https:// creativecommons.org/licenses/by/ $4.0 /)$.
Abstract: The accelerated ageing of wood in terms of heating or iron rusting has a potential effect on the physio-mechanical, chemical and biological properties of wood. The effects of accelerated ageing on the mechanical, physical and fungal activity properties of some wood materials (Schinus terebinthifolius, Erythrina humeana, Tectona grandis, Pinus rigida and Juglans nigra) were studied after several cycles of heating and iron rusting. The fungal activity was assayed against the growth of Aspergillus terreus, Aspergillus niger, Fusarium culmorum and Stemphylium solani. In addition, the mechanical and optical properties of paper sheets produced from those wood pulps by means of Kraft cooking were evaluated. The mechanical and chemical properties of the studied wood species were affected significantly $(p<0.05)$ by the accelerated ageing, compared to control woods. With Fourier transform infrared (FTIR) spectroscopy, we detected an increase in the intensity of the spectra of the functional groups of cellulose in the heated samples, which indicates an increase in cellulose content and decrease in lignin content, compared to other chemical compounds. For pulp properties, woods treated by heating showed a decrease in the pulp yield. The highest significant values of tensile strength were observed in pulp paper produced from untreated, heated and iron-rusted $P$. rigida wood and they were $69.66,65.66$ and $68.33 \mathrm{~N} \cdot \mathrm{m} / \mathrm{g}$, respectively; we calculated the tear resistance from pulp paper of untreated P. rigida $\left(8.68 \mathrm{mN} \cdot \mathrm{m}^{2} / \mathrm{g}\right)$ and $T$. grandis $\left(7.83 \mathrm{mN} \cdot \mathrm{m}^{2} / \mathrm{g}\right)$ and rusted $P$. rigida $\left(7.56 \mathrm{mN} \cdot \mathrm{m}^{2} / \mathrm{g}\right)$ wood; we obtained the values of the burst strength of the pulp paper of untreated woods of $P$. rigida $\left(8.19 \mathrm{kPa} \cdot \mathrm{m}^{2} / \mathrm{g}\right)$ and $T$. grandis $\left(7.49 \mathrm{kPa} \cdot \mathrm{m}^{2} / \mathrm{g}\right)$, as well as the fold number of the pulp paper of untreated, heated and rusted woods from P. rigida, with values of 195.66, 186.33 and 185.66, respectively. After 14 days from the incubation, no fungal inhibition zones were observed. Accelerated ageing (heated or iron-rusted) produced significant effects on the mechanical and chemical properties of the studied wood species and affected the properties of the produced pulp paper.

Keywords: iron rust; mechanical properties; wood pulp; Fourier transform infrared spectroscopy; accelerated ageing

\section{Introduction}

Wood, as a natural material, can be deteriorated by biodegradation, weathering and ageing. Weathering (the slow degradation of materials exposed to the weather) and 
accelerated weathering (the laboratory emulation of the damaging factors of weather for the aim of anticipating the relative strength of materials exposed to outdoor environments) have been studied for their effects on the properties of wood [1-8]. By investigating the heat treatment, the ageing mechanism of wood can be evaluated $[9,10]$. Heat, under dry circumstances, is assumed to be accompanied by thermal oxidation of the wood ingredients, whereas, under wet conditions, the participation of hydrolysis can be more frequently expected [11-13]. A lower equilibrium of the moisture content was found as a result from thermally treating wood [14].

A weakening in wood can be observed by the corrosion of metal linked with wood in different shapes, such as spikes, bolts, boat docks, nails, screws, plates, rail ties and wooden vessels $[15,16]$. The degradation of the wood around the fastener is caused by the severely corroding metal corrosion products, when preservative or fire treatments are utilized [17], as well as by the occurrence of $\mathrm{H}_{2} \mathrm{O}$ and $\mathrm{O}_{2}$ in the cellular structure of wood [18].

Wet wood not only causes metals to corrode, but certain conditions are created when a metal is embedded in wet wood, which can accelerate the corrosion of the metal [19]. Strength loss occurs as a result of the corrosion of the metal with the deterioration of the wood. The wooden parts surrounding the nails are usually stained black and degraded because of the acid that accumulates in the crevice and wood fibers $[15,20]$.

Furthermore, the corrosion of metals embedded in wood are affected by three groups of extractives organic acids (found in black liquors of wood pulp), tannins and phenols [21]. Fungal pathogens require from $10^{-7}$ to $10^{-6} \mathrm{M}$ iron for their growth $[22,23]$ and iron in the status of $\mathrm{Fe}(\mathrm{II})$ and $\mathrm{Fe}(\mathrm{III})$ is required by most living systems [24]. Iron is used as a cofactor for oxidation-reduction enzymes and it is essential for fungal metabolism to prevent repolymerization and toxicity [25]. In the form of phenolate, iron is produced by the wood-rotting fungus Gloeophyllum trabeum that conjugates with cellulose and activates the degradation mechanism [26]. On the other hand, excess iron is toxic, as it mediates the formation of potentially deleterious free radicals, and the inactivation of iron assimilation mechanisms attenuates the virulence of major fungal pathogens such as Candida albicans and Cryptococcus neoformans [27].

Iron is required by most living systems, since it has two readily available ionization states, $\mathrm{Fe}(\mathrm{II})$ and $\mathrm{Fe}(\mathrm{III})$ [28], and it is an essential micronutrient for most organisms. Fungal pathogens require from $10^{-7}$ to $10^{-6} \mathrm{M}$ iron for their growth [22]. On the other hand, excess iron is toxic, as it mediates the formation of potentially deleterious free radicals [27]. Iron is toxic in uncontained situations because it catalyzes the production of free radicals. Therefore, after uptake, storage of the accessed iron becomes essential in the fungal metabolism of the metal to prevent repolymerization and toxicity [28].

In the last years of the 19th century, with the increasing demand for paper and the scarce availability of cellulose fibers from linen, agricultural residues and cotton [29-31], wood became the main source of this compound. It is evident that the evolution in the manufacture of paper through the centuries clearly shows a marked modification in its structure, both in relation to the origin of cellulose fibers [32] and to the types of additives used. In this context, the process of sizing plays a key role, directly affecting the mechanism of water and ink absorption by paper fibers [33]. Iron ions, as impurities, can catalyze the oxidation processes in cellulose, probably as centers able to form free radicals through a sequence of Fenton reactions [34]. Paper products are always faced with physical damages, such as yellowing and pollution problems [35], because of the low glass transition temperature $\left(\mathrm{T}_{\mathrm{g}}\right)$. Regarding the physical characteristics, the most proper material for the restoration of paper products should always necessarily meet two demands, including legibility (transparency) and durability against ageing [36].

Wood, wood-derived paper sheets and iron are indispensable materials widely used in construction, furniture and various tools. The combined use of these materials is necessary for many purposes and, as such, the contact between iron and wood/paper sheets is unavoidable. Under natural and room conditions, iron can rust and the formed rust likely promotes the ageing of the wood and paper sheet with which it comes into contact, 
resulting in changes in their physical, chemical and biological properties. To provide a detailed understanding of these potential effects, this study was carried out. This is an issue that needs to be studied because the rusting process of iron adjacent to the wood can negatively affect system performance. Therefore, this work aims at evaluating the effect of heating and iron rusting on the physical, mechanical, chemical and biological properties of five wood species subjected to accelerated ageing. Additionally, the produced pulp paper from those woods were evaluated in terms of their mechanical and optical properties.

\section{Materials and Methods}

\subsection{Preparation of Raw Materials}

Samples of stem wood were used from two local tree species, Schinus terebinthifolius and Erythrina humeana, beside three imported woods, Tectona grandis, Pinus rigida and Juglans nigra. All wood samples were air-dried at laboratory conditions (temperature of $27 \pm 3{ }^{\circ} \mathrm{C}$ and relative humidity (RH) of $65 \pm 5 \%$ ). Wood samples were prepared with different dimensions, namely, $2.5 \mathrm{~cm} \times 2.5 \mathrm{~cm} \times 10 \mathrm{~cm}, 30 \mathrm{~cm} \times 2 \mathrm{~cm} \times 2 \mathrm{~cm}$ and $30 \mathrm{~cm} \times 2 \mathrm{~cm} \times 0.6 \mathrm{~cm}$. Samples from each wood were divided into three groups: samples from the first group were left in their air-drying status as control treatment; the second group was subjected to accelerated ageing in water (heated); the third group was subjected to accelerated ageing in water suspended with iron rust. There were three replicates for each mechanical characteristic studied. Three wood samples from each wood species were used for each treatment.

\subsection{Ageing Processes}

Several studies have been conducted to measure the accelerated exposure test that consists in the exposure of samples to certain conditions of temperature and humidity, based on the standard methods and from the published literature [11,17,37-44]. In order to obtain a realistic simulation of the wooden elements in contact with iron in the surrounding environment, accelerated artificial ageing stages were carried out on the wood samples of the second group through four successive cycles. One cycle consisted of four steps, as shown in Table $1[45,46]$.

Table 1. Accelerated ageing steps for wood samples.

\begin{tabular}{cccc}
\hline Step & Exposure & Temperature $\left({ }^{\circ} \mathbf{C}\right)$ & Time (h) \\
\hline 1 & Water soak & 49 & 2 \\
2 & Dry-air heat & 99 & 4 \\
3 & Water soak & 49 & 2 \\
4 & Dry-air heat & 99 & 16 \\
\hline
\end{tabular}

The four stages in Table 1 represent one ageing cycle; this cycle was repeated four consecutive times for the second group of samples (heated woods). On the other hand, the third group of samples was subjected to the same above-mentioned stages, but with water being replaced by water suspended with iron rust ( $100 \mathrm{~g} / \mathrm{L}$ of water) (iron-rusted woods). This means that the iron-rust solution used in the ageing process for the third group of samples was prepared by adding $100 \mathrm{~g}$ per liter $(10 \%)$ of water and stirring to obtain the iron rust suspension. This method somewhat simulates the case of wood coming into contact with iron and being exposed to high levels of relative humidity in the surrounding atmosphere, or immersed in water or in moist soil.

\subsection{Mechanical, Physical, Chemical and Biological Properties \\ 2.3.1. Mechanical and Physical Properties}

After sample conditioning [47], the tested wood samples were measured for their mechanical properties according to the British standard specification [48]. Three mechanical tests were carried out, namely, compression strength $\left(C_{\max }\right)$ parallel to grain $(\mathrm{MPa})$, modulus of rupture (MOR) in bending (MPa) and maximum tensile strength (MTS) parallel 
to grain (MPa). All tests were carried out using the Quasar $600 \mathrm{kN}$ instrument (Galdabini Spa, Cardano al Campo, Italy). The static quality value was calculated as a ratio of the crushing strength parallel to the grain and 100 $\times$ air-dry density of wood [49-51].

The wood species were prepared in different dimensions: $2.5 \mathrm{~cm} \times 2.5 \mathrm{~cm} \times 10 \mathrm{~cm}$ to measure the compression parallel to grain [52]; $30 \mathrm{~cm} \times 2 \mathrm{~cm} \times 2 \mathrm{~cm}$ to test static bending strength [48]; $30 \mathrm{~cm} \times 2 \mathrm{~cm} \times 0.6 \mathrm{~cm}$ to test the tensile strength parallel to grain [48].

The density of wood and moisture content (MC\%) were determined after the bendingstrength test by cutting off at least three pieces with the dimension $2 \mathrm{~cm} \times 2 \mathrm{~cm} \times 1.5 \mathrm{~cm}$ near the failure region [53]. Based on the oven-dry weight (o.d.) and volume at the time of testing, the density of each specimen was calculated using the dimension method [54], while the MC was determined based on the o.d. weight [55].

The mechanical and physical properties of the age-accelerated groups (heated and iron-rusted) were compared with the control group (without accelerated ageing).

\subsubsection{Chemical Composition of Wood Species}

All wood samples (untreated, heated and iron-rusted) were chipped, fractionated using a knife mill and screened; the size of the chips was set as $20 \mathrm{~mm}$ long and $13 \mathrm{~mm}$ wide. The samples from homogenized wood chips from $S$. terebinthifolius, E. humeana, T. grandis, P. rigida and J. nigra were milled and sieved and the 40-60 mesh fraction was used for the summative chemical analysis. The extractive contents (alcohol and benzene) were obtained using extraction thimbles in a Soxhlet apparatus for no less than $16 \mathrm{~h}$ according to the TAPPI standard method (T204). The thimbles were oven-dried and weighted after each extraction determining the extractive content by weight variation. Holocellulose was determined by using the modified chlorite TAPPI standard method T249; the insoluble lignin content was determined according to the TAPPI standard method (T222 om88). Ash content was determined by the TAPPI standard method (T211). All summative chemical analyses were reported as percentages of the initial mass.

\subsubsection{FTIR Spectroscopic Analysis of Accelerated Ageing of Wood Samples}

The wood samples were analyzed with a Nicolet 380 FT-IR Spectrometer (Madison, WI, USA) using the solid-sample potassium bromide technique, at the National Institute for Measurement and Calibration, Tersa, Giza, Egypt, using the KBr pellet method at a resolution of $4 \mathrm{~cm}^{-1}$ ranging from 400 to $4000 \mathrm{~cm}^{-1}$. Standard $\varnothing 13 \mathrm{~mm}$ diameter pellets were prepared by mixing and pressing $10 \mathrm{mg}$ of the dried wood extractive sample in $300 \mathrm{mg}$ of $\mathrm{KBr}$ for $5 \mathrm{~min}$ under a pressure of 200 bar. Three parallel measurements were performed. The obtained FTIR spectra were further processed using the computer software Spectrum One (ver. 5.0.1) [56-58].

\subsubsection{Biological Activity of Accelerated Ageing of Five Wood Species In Vitro}

Wood blocks of $15 \mathrm{~mm} \times 10 \mathrm{~mm} \times 5 \mathrm{~mm}$ from each wood type were autoclaved at $121^{\circ} \mathrm{C}$ for $20 \mathrm{~min}$ and left to cool. Figure 1 shows two groups (heated and iron-rusted) of five age-accelerated wood species and the control that were studied for their antifungal activity against four molds, namely, Aspergillus terreus Ate456, A. niger Ani245, Fusarium culmorum Fcu761 and Stemphylium solani Ssol382. A 14-day-old PDA culture of each fungus was prepared. After ageing, the groups of wood samples were inoculated with a disc ( $5 \mathrm{~mm}$ in diameter) of each fungus in a Petri dish that contained $15 \mathrm{~mL}$ of PDA culture and were incubated for one and two weeks at $25 \pm 1{ }^{\circ} \mathrm{C}$. Three replicates were used for each type of ageing samples. Five samples without ageing were used as control samples. Visual observation after 7 and 14 days of each group of wood samples against each fungus was performed and recorded using the recommendations of previously published works [59-63]. 


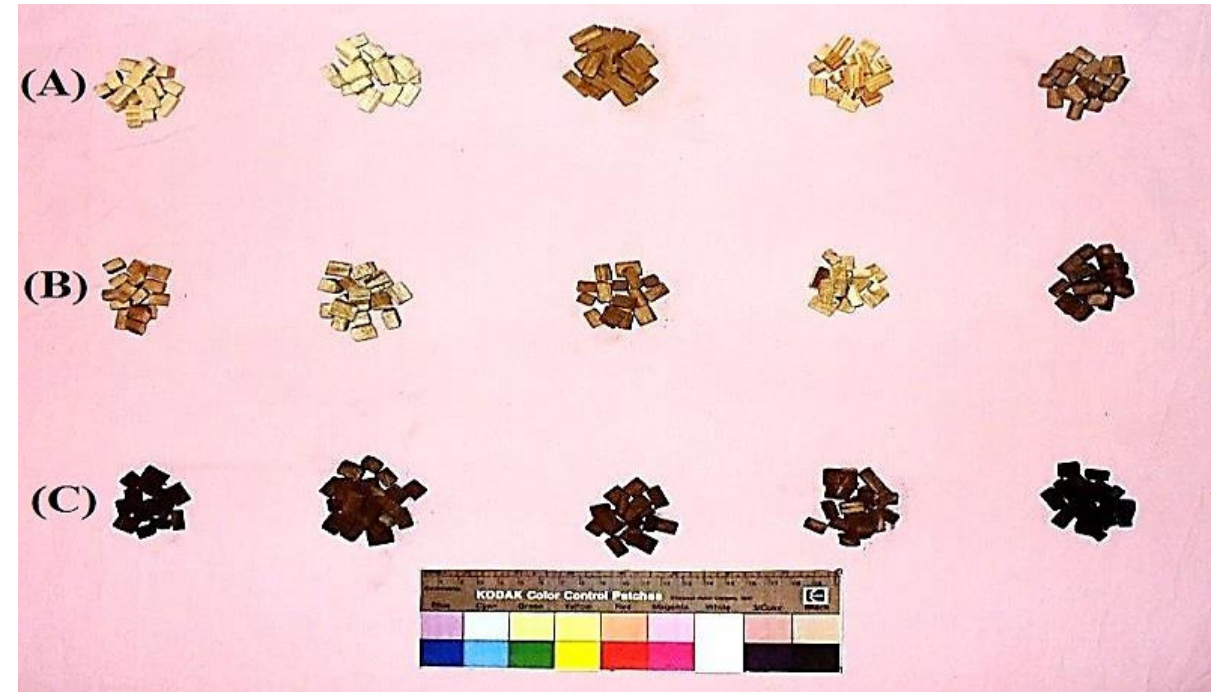

Figure 1. Groups of five age-accelerated wood species: (A) control, (B) heated and (C) rusted.

\subsection{Pulp Production \\ 2.4.1. Kraft Pulping}

Two hundred grams of o.d. wood chips from each wood species was swelled for one day, filtrated and impregnated in a sodium hydroxide $8 \%$ solution for $1 \mathrm{~h}$ at $85^{\circ} \mathrm{C}$; then, it was filtrated and washed from residual alkali with hot water at $70{ }^{\circ} \mathrm{C}$.

Kraft pulping was conducted in a stainless-steel vessel with a capacity of $3 \mathrm{~L}$ under rotation in an oil bath. The cooking of wood chips ( $200 \mathrm{~g}$ based on o.d. weight) was carried out in two distinct stages. The first stage was a pretreatment, where wood chips were impregnated in a sodium hydroxide $3 \%$ solution for $4 \mathrm{~h}$ at $85{ }^{\circ} \mathrm{C}$, then washed with hot water at $70{ }^{\circ} \mathrm{C}$. The second stage is referred to as the post kraft cooking and was conducted for an additional $2.5 \mathrm{~h}$. The wood pulping conditions were as follows, for all samples: active alkalinity charge, $18 \%$; sulfidity, as sodium oxide, $20 \%$; $175^{\circ} \mathrm{C}$ cooking temperature; liquor ratio (liquid-to-wood chips ratio), 7:1. Subsequently, at the end of the cooking process, the rest of the chip pulp was disintegrated with a standard pulp disintegrator in $2 \mathrm{~L}$ of water for $15 \mathrm{~min}$ (about 50,000 revolutions). The solid residue was defibrated, washed with hot and cold water till neutral $\mathrm{pH}$ was reached; the resulting pulp was screened in a Valley flat screen having $0.25 \mathrm{~mm}$ slots and beat (Valley beater method), according to the TAPPI standard method T200 sp-96. All the wood chips were pulped in triplicate. Yield, Kappa number and freeness of pulp (Canadian standard method) were determined according to the TAPPI standard methods T210 cm-93, T236 om-13 and T227 om-99, respectively.

\subsubsection{Sheet Formation and Paper Testing}

The wood pulp was made into standard handsheets samples $\left(200 \mathrm{~cm}^{2}\right)$ with a grammage of about $60 \mathrm{~g} / \mathrm{m}^{2}$ (TAPPI Standard T $205 \mathrm{sp}-02$ ) for determination of dry strength properties; the samples were conditioned at $50 \pm 2 \%$ relative humidity and $23 \pm 1{ }^{\circ} \mathrm{C}$ temperature according to TAPPI T $402 \mathrm{sp}-98$ for at least $4 \mathrm{~h}$. Paper sheets (Figure 2) were made and tested for strength properties according to the TAPPI test methods T218 and T220. The handsheets were tested for tensile resistance (T403), tear strength (T414), bursting strength (T405), double fold number (T423) and optical properties (T452 om-92). All testing was in accordance with TAPPI standard test methods. 


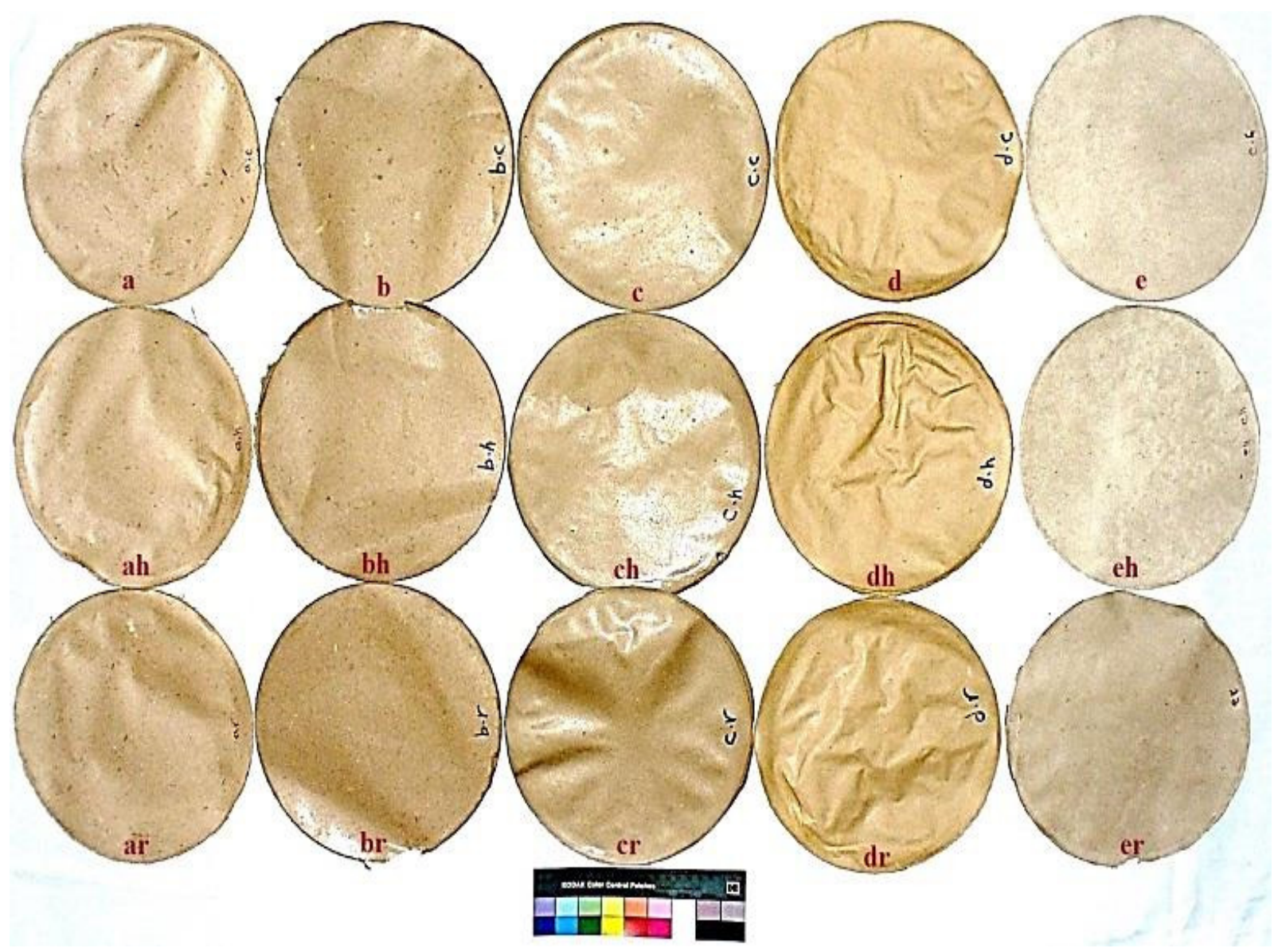

Figure 2. Paper sheets produced from wood species and after heating and iron rusting treatments; Schinus terebinthifolius (a), Erythrina humeana (b), Tectona grandis (c), Pinus rigida (d) and Juglans nigra (e). h, heated; r, iron-rusted.

\subsection{Statistical Analyses}

The data were statistically analyzed with a two-way analysis of variance (ANOVA) using the SAS software [64], where the two factors were wood species and wood treatments (control, heated and iron-rusted). The comparisons among the treatments was measured using LSD 0.05 .

\section{Results}

\subsection{Properties of Age-Accelerated Wood}

\subsubsection{Mechanical and Physical Properties of Age-Accelerated Woods}

Table 2 and Figure 3 present the values of selected mechanical and physical properties of the studied wood species subjected to different treatments (heated and iron-rusted), compared to control treatment (untreated wood). It can be seen that the highest MOR values were 144.18 and $139.65 \mathrm{MPa}$, obtained from rusted J. nigra and heated P. rigida wood, respectively, followed by untreated T. grandis wood (129.18 MPa), untreated J. nigra wood $(126.10 \mathrm{MPa})$, rusted P. rigida wood $(124.87 \mathrm{MPa})$ and T. rusted grandis wood (123.70 MPa). The lowest values observed were obtained from untreated, heated and rusted E. humeana wood with values of 28.91, 28.03 and $23.53 \mathrm{MPa}$, respectively. The highest values of maximum tensile strengths (MTS) were observed in the untreated wood of P. rigida (130.52 MPa), T. grandis (109.85 MPa) and J. nigra (103.17 MPa) and in heated T. grandis wood (102.32 MPa). Untreated, heated and rusted E. humeana wood showed the lowest MTS values-20.74, 16.29 and $16.38 \mathrm{MPa}$, respectively. The maximum crushing strength $\left(\mathrm{C}_{\max }\right)$ values were reported for untreated, heated and rusted $T$. grandis wood, with values of $65.26,64.46$, $58.75 \mathrm{MPa}$, respectively, while the lowest values were observed in tested untreated, heated 
and rusted E. humeana wood, with values of $11.94,12.12$ and $13.54 \mathrm{MPa}$, respectively. Other treated woods showed values ranging from 43.40 to $57.82 \mathrm{MPa}$.

As for the density of the tested woods, the statistical model used showed no significant differences among the samples, but the highest density values were found in all wood species within their treatments $\left(0.538-0.599 \mathrm{~g} / \mathrm{cm}^{3}\right)$ except for the values obtained from E. humeana wood $\left(0.214-0.227 \mathrm{~g} / \mathrm{cm}^{3}\right)$. The moisture content for all the tested wood species and their treatments was in the range of $7.34-12.51 \%$, with no significant differences among the samples.

Table 2. Effect of heat and rust treatments on the mean values of the selected physical and mechanical properties of the five wood species.

\begin{tabular}{|c|c|c|c|c|c|c|}
\hline Wood Species & Treatment & $\begin{array}{l}\text { MOR } \\
\text { (MPa) }\end{array}$ & $\begin{array}{l}\text { MTS } \\
\text { (MPa) }\end{array}$ & $\begin{array}{l}\mathrm{C}_{\max } \\
\text { (MPa) }\end{array}$ & $\begin{array}{l}\text { Density } \\
\left(\mathrm{g} / \mathrm{cm}^{3}\right)\end{array}$ & $\begin{array}{l}\text { MC } \\
(\%)\end{array}$ \\
\hline \multirow{3}{*}{ Erythrina humeana } & Control & $28.91 \pm 2^{\mathrm{H}}$ & $20.74 \pm 2^{I}$ & $11.94 \pm 1.4^{\mathrm{G}}$ & $0.227 \pm 0.04$ & $12.51 \pm 0.75$ \\
\hline & Heated & $28.03 \pm 3^{\mathrm{H}}$ & $16.29 \pm 4^{I}$ & $12.12 \pm 1.9^{\mathrm{G}}$ & $0.227 \pm 0.02$ & $10.31 \pm 0.56$ \\
\hline & Rusted & $23.53 \pm 6^{\mathrm{H}}$ & $16.38 \pm 4^{\mathrm{I}}$ & $13.54 \pm 1.5^{\mathrm{G}}$ & $0.214 \pm 0.01$ & $10.11 \pm 0.13$ \\
\hline \multirow{3}{*}{ Pinus rigida } & Control & $120.46 \pm 8^{\text {C-E }}$ & $130.52 \pm 4^{\mathrm{A}}$ & $57.82 \pm 3.0^{\mathrm{BC}}$ & $0.595 \pm 0.02$ & $11.34 \pm 0.28$ \\
\hline & Heated & $139.65 \pm 20 \mathrm{AB}$ & $60.18 \pm 8 \mathrm{GH}$ & $52.90 \pm 8.2^{\mathrm{DE}}$ & $0.599 \pm 0.04$ & $10.53 \pm 0.14$ \\
\hline & Rusted & $124.87 \pm 11 \mathrm{CD}$ & $89.89 \pm 21 \mathrm{DE}$ & $53.01 \pm 4.9 \mathrm{DE}$ & $0.594 \pm 0.03$ & $9.91 \pm 0.33$ \\
\hline \multirow{3}{*}{ Schinus terebinthifolius } & Control & $102.70 \pm 4^{\mathrm{G}}$ & $80.22 \pm 6^{\mathrm{EF}}$ & $54.45 \pm 0.6^{\mathrm{C}-\mathrm{E}}$ & $0.538 \pm 0.02$ & $11.82 \pm 0.67$ \\
\hline & Heated & $105.96 \pm 8^{\mathrm{F}}$ & $64.81 \pm 15^{\mathrm{G}}$ & $43.40 \pm 6.3^{\mathrm{F}}$ & $0.558 \pm 0.04$ & $10.33 \pm 0.42$ \\
\hline & Rusted & $112.05 \pm 10^{\mathrm{E}-\mathrm{G}}$ & $50.93 \pm 5^{\mathrm{H}}$ & $51.99 \pm 5.5^{\mathrm{E}}$ & $0.576 \pm 0.02$ & $11.93 \pm 3.35$ \\
\hline \multirow{3}{*}{ Tectona grandis } & Control & $129.18 \pm 21^{\mathrm{BC}}$ & $109.85 \pm 26^{\mathrm{B}}$ & $65.26 \pm 1.3^{\mathrm{A}}$ & $0.588 \pm 0.04$ & $10.00 \pm 0.46$ \\
\hline & Heated & $115.79 \pm 9^{\mathrm{D}-\mathrm{F}}$ & $102.32 \pm 12^{\mathrm{BC}}$ & $64.46 \pm 3.2^{\mathrm{A}}$ & $0.544 \pm 0.02$ & $8.45 \pm 0.15$ \\
\hline & Rusted & $123.70 \pm 7 \mathrm{CD}$ & $94.24 \pm 3^{C D}$ & $58.75 \pm 4.0^{\mathrm{B}}$ & $0.561 \pm 0.01$ & $7.34 \pm 0.25$ \\
\hline \multirow{3}{*}{ Juglans nigra } & Control & $126.10 \pm 25^{C D}$ & $103.17 \pm 17^{\mathrm{BC}}$ & $45.09 \pm 5.4^{\mathrm{F}}$ & $0.550 \pm 0.07$ & $10.07 \pm 0.51$ \\
\hline & Heated & $107.23 \pm 12^{\mathrm{FG}}$ & $83.59 \pm 22 \mathrm{DE}$ & $55.61 \pm 5.4^{\mathrm{B}-\mathrm{D}}$ & $0.543 \pm 0.03$ & $8.67 \pm 0.22$ \\
\hline & Rusted & $144.18 \pm 15^{\mathrm{A}}$ & $69.80 \pm 10$ FG & $51.60 \pm 5.6^{\mathrm{E}}$ & $0.565 \pm 0.08$ & $9.32 \pm 0.69$ \\
\hline $\mathrm{LSD}_{0.05}$ & & 11.67 & 12.21 & 3.96 & NS & NS \\
\hline
\end{tabular}

Each value is an average of three samples. $C_{\max }=$ the compression strength parallel to grain (MPa) at about $12 \%$ moisture content, MTS, maximum tensile strength. Means with the letter/s within the same column are not significantly different according to LSD 0.05.

\subsubsection{Chemical Composition of the Raw Materials}

Table 3 shows the chemical analysis of the studied wood species as affected by heating or iron-rusted, compared with untreated woods (control). The highest contents (\%) of the alcohol and benzene extractives were recorded in the untreated woods from S. terebinthifolius, T. grandis and E. humeana, with percentages of $9.30,8.23$ and $8.16 \%$, respectively, while the rusted, heated and control woods of $P$. rigida showed the lowest amounts, with percentages of $2.56,3.33$ and $4.36 \%$, respectively. The lignin content (\%) was found in high percentages in the untreated, heated and rusted wood from T. grandis, with values of 29.33, 29.66 and $29.66 \%$, respectively, and in rusted $P$. rigida $(29.60 \%)$, while the lowest amounts were observed in the untreated, heated and rusted wood of J. nigra with values of 22, 22.33 and 22.60, respectively. J. nigra wood showed the highest content of holocellulose, with $69.97 \%$ (untreated), $71.25 \%$ (heated) and $71.46 \%$ (rusted), while T. grandis wood showed the lowest content of holocellulose, with $59.95 \%$ (untreated), $61.22 \%$ (heated) and $61.34 \%$ (rusted). Untreated and heated wood of E. humeana showed the highest amount of ash content, with percentages of 3.96 and $3.40 \%$, respectively, followed by untreated woods from $T$. grandis $(2.86 \%)$, S. terebinthifolius $(2.86 \%)$ and E. humeana $(2.37 \%)$; P. rigida wood showed the lowest ash content among the studied wood samples with percentages of $0.85 \%$ (heated) and $0.43 \%$ (rusted), while from rusted J. nigra wood we obtained a value of $0.621 \%$. 


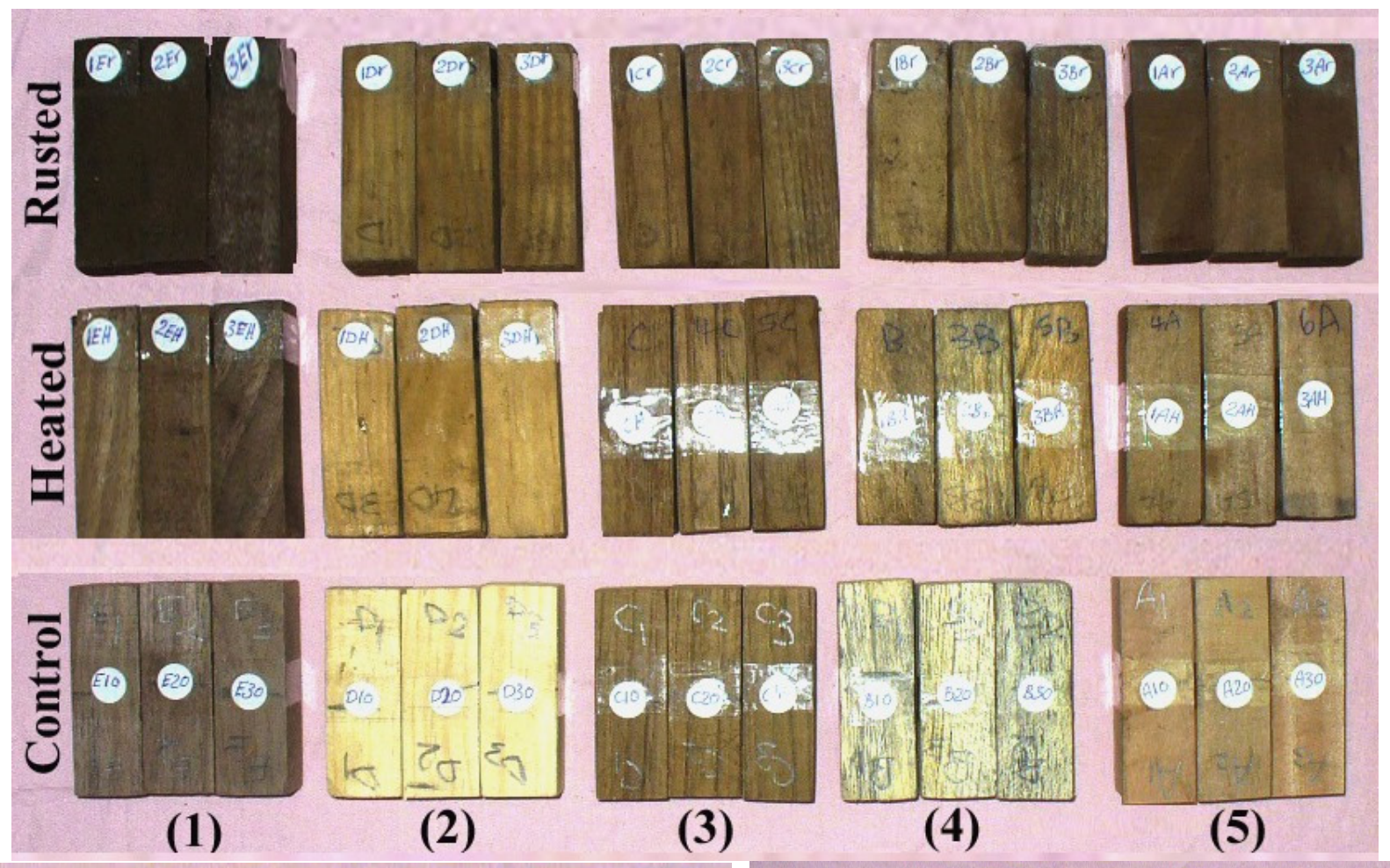

- 0 o ja

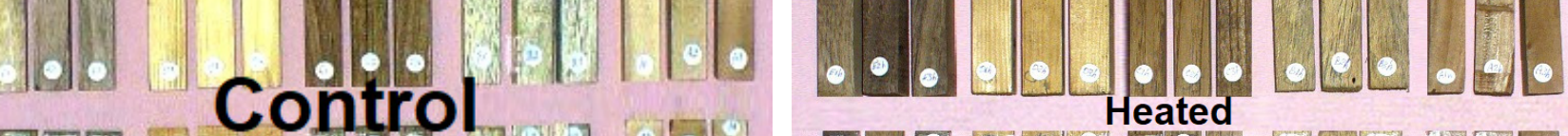

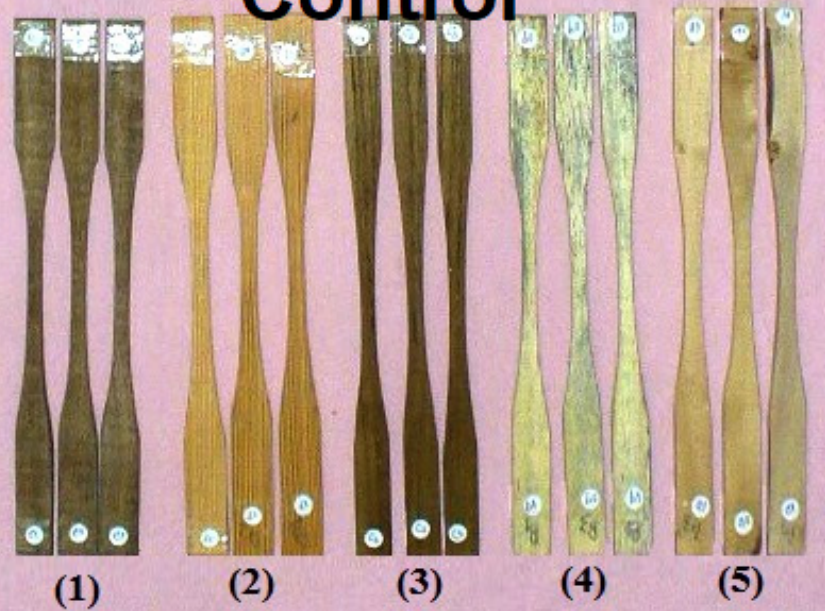

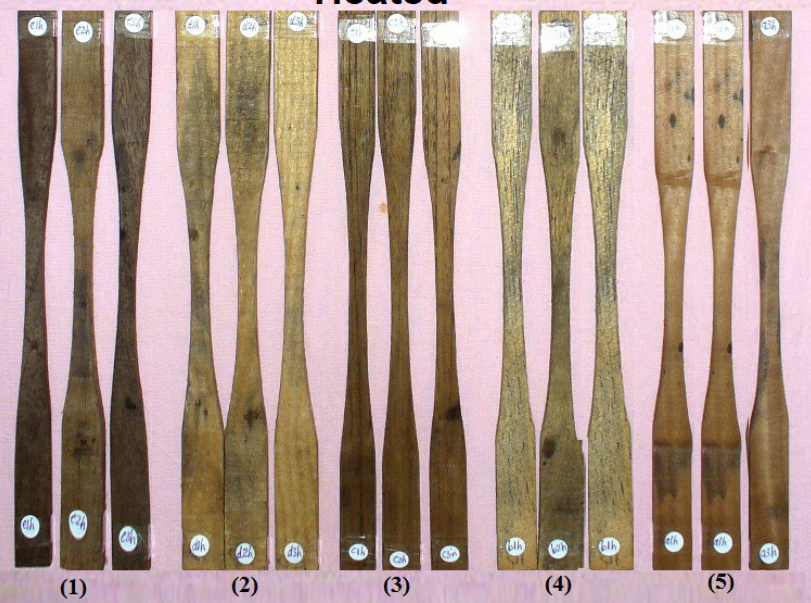

Figure 3. Cont. 


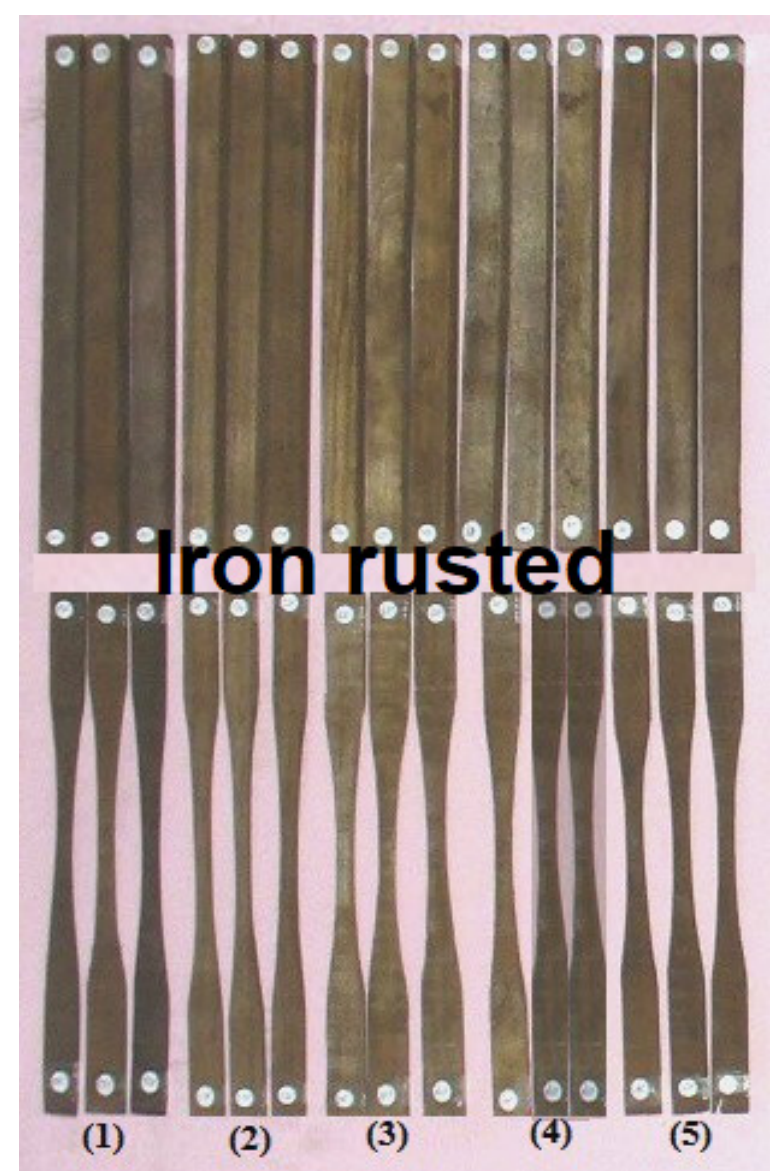

Figure 3. Wood samples with different treatments (heated and rusted woods) compared to control treatment (untreated wood) prepared for the testing of their mechanical properties. (1) Schinus terebinthifolius, (2) Pinus rigida, (3) Tectona grandis, (4) Erythrina humeana and (5) Juglans nigra.

Table 3. Chemical composition of the wood samples.

\begin{tabular}{|c|c|c|c|c|c|}
\hline Wood Species & Treatment & $\begin{array}{c}\text { Alcohol:benzene } \\
\text { Extractives Content (\%) }\end{array}$ & Lignin Content (\%) & $\begin{array}{l}\text { Holocellulose } \\
\text { Content (\%) }\end{array}$ & Ash Content (\%) \\
\hline \multirow{3}{*}{ Tectona grandis } & Control & $8.23 \pm 0.05^{\mathrm{B}}$ & $29.33 \pm 0.57 \mathrm{AB}$ & $59.95 \pm 0.005^{\mathrm{N}}$ & $2.86 \pm 0.01^{C}$ \\
\hline & Heated & $7.16 \pm 0.005^{\mathrm{E}}$ & $29.66 \pm 0.57^{\mathrm{A}}$ & $61.22 \pm 0.005^{\mathrm{M}}$ & $1.96 \pm 0.05^{G}$ \\
\hline & Rusted & $6.83 \pm 0.05^{\mathrm{F}}$ & $29.66 \pm 0.57^{\mathrm{A}}$ & $61.34 \pm 0.005^{\mathrm{L}}$ & $1.87 \pm 0.01^{\mathrm{H}}$ \\
\hline \multirow{3}{*}{ Schinus terebinthifolius } & Control & $9.30 \pm 0.10^{\mathrm{A}}$ & $24.33 \pm 0.57^{\mathrm{G}}$ & $63.76 \pm 0.11^{\mathrm{I}}$ & $2.86 \pm 0.05^{\mathrm{C}}$ \\
\hline & Heated & $7.85 \pm 0.005^{C}$ & $25.56 \pm 0.05^{\mathrm{F}}$ & $64.56 \pm 0.05^{\mathrm{H}}$ & $2.03 \pm 0.01^{\mathrm{F}}$ \\
\hline & Rusted & $7.65 \pm 0.005^{\mathrm{D}}$ & $24.33 \pm 0.57^{\mathrm{G}}$ & $65.82 \pm 0.01^{\mathrm{F}}$ & $1.52 \pm 0.005^{\mathrm{I}}$ \\
\hline \multirow{3}{*}{ Erythrina humeana } & Control & $8.16 \pm 0.01^{\mathrm{B}}$ & $25.66 \pm 0.57^{\mathrm{EF}}$ & $61.86 \pm 0.02^{\mathrm{K}}$ & $3.96 \pm 0.005^{\mathrm{A}}$ \\
\hline & Heated & $7.77 \pm 0.01^{C D}$ & $26.66 \pm 0.57 \mathrm{DE}$ & $62.91 \pm 0.005 \mathrm{~J}$ & $3.40 \pm 0.1^{\mathrm{B}}$ \\
\hline & Rusted & $5.55 \pm 0.005^{\mathrm{H}}$ & $26.33 \pm 0.57^{\mathrm{EF}}$ & $64.50 \pm 0.10^{\mathrm{H}}$ & $2.85 \pm 0.005^{\mathrm{C}}$ \\
\hline \multirow{3}{*}{ Pinus rigida } & Control & $4.36 \pm 0.208^{\mathrm{J}}$ & $28.43 \pm 0.11^{\mathrm{BC}}$ & $64.92 \pm 0.01^{G}$ & $2.37 \pm 0.01^{\mathrm{D}}$ \\
\hline & Heated & $3.33 \pm 0.02^{\mathrm{K}}$ & $27.66 \pm 1.52^{C D}$ & $66.63 \pm 0.208^{\mathrm{E}}$ & $0.85 \pm 0.005^{\mathrm{K}}$ \\
\hline & Rusted & $2.56 \pm 0.05^{\mathrm{L}}$ & $29.60 \pm 0.20^{\mathrm{A}}$ & $67.15 \pm 0.01^{\mathrm{D}}$ & $0.43 \pm 0.005^{\mathrm{M}}$ \\
\hline \multirow{3}{*}{ Juglans nigra } & Control & $6.86 \pm 0.005^{\mathrm{F}}$ & $22 \pm 1^{\mathrm{H}}$ & $69.97 \pm 0.01^{C}$ & $2.14 \pm 0.01^{\mathrm{E}}$ \\
\hline & Heated & $5.73 \pm 0.05^{\mathrm{G}}$ & $22.33 \pm 0.57^{\mathrm{H}}$ & $71.25 \pm 0.01^{\mathrm{B}}$ & $0.93 \pm 0.005 \mathrm{~J}$ \\
\hline & Rusted & $5.16 \pm 0.11^{\mathrm{I}}$ & $22.60 \pm 0.20^{\mathrm{H}}$ & $71.46 \pm 0.03^{\mathrm{A}}$ & $0.62 \pm 0.01^{\mathrm{L}}$ \\
\hline LSD 0.05 & & 0.1224 & 1.09 & 0.116 & 0.057 \\
\hline$p$-value & & $<0.0001$ & 0.0336 & $<0.0001$ & $<0.0001$ \\
\hline
\end{tabular}

Means with the same letter/s within the same column are not significantly different according to LSD 0.05 . 


\subsubsection{FTIR Analyses of Accelerated Ageing of Wood Samples}

Fourier transform infrared (FTIR) spectroscopy is considered an established technique used to determine the chemical composition of various chemical samples $[57,65-67]$. The intensities of the functional chemical groups are reported in Table 4. The FTIR spectra of the aged wood samples are presented in Figures 4-8.

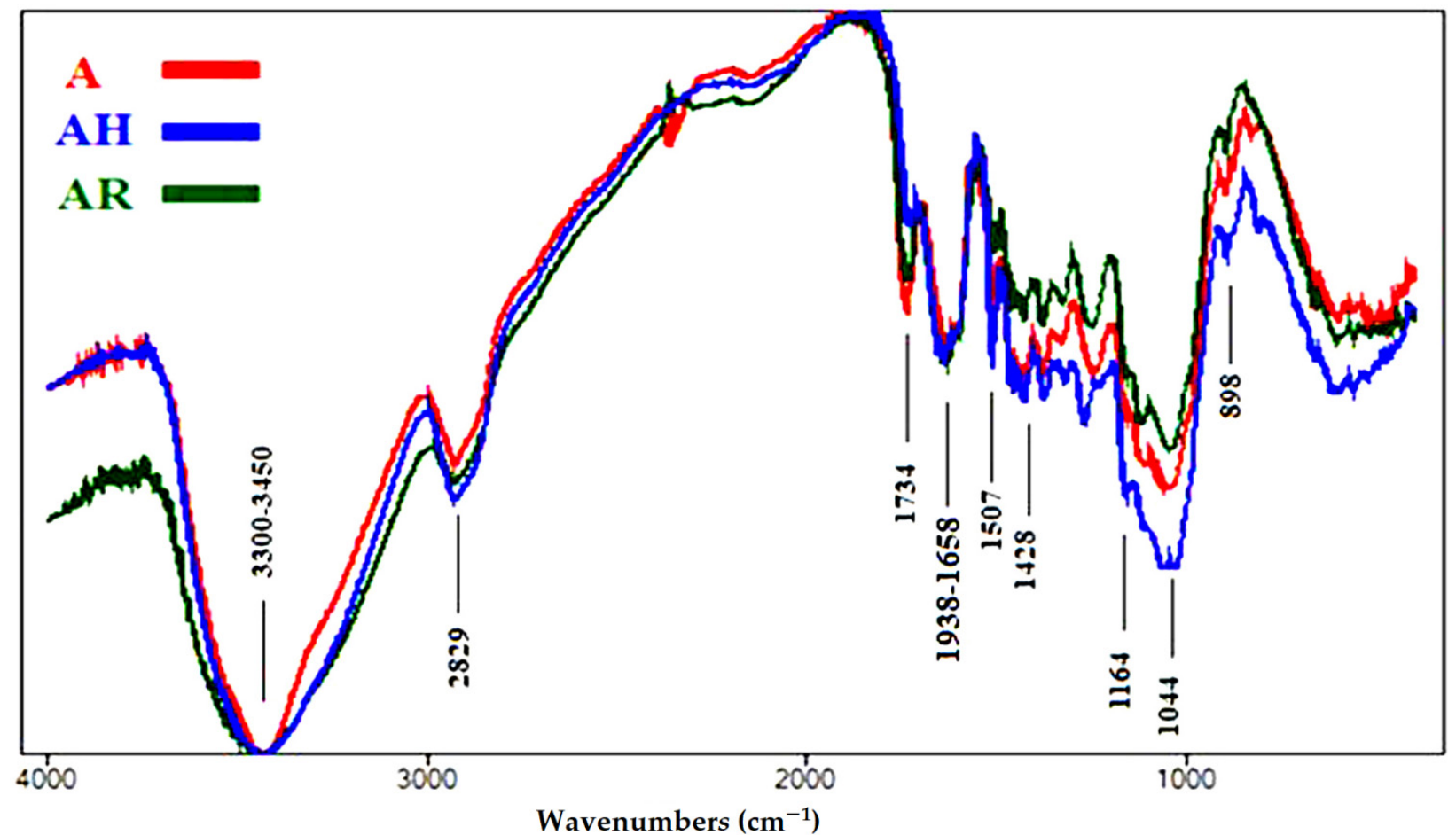

Figure 4. FTIR spectra of the wood samples of Schinus terebinthifolius (A, control; AH, heated ageing; AR, rusted ageing).

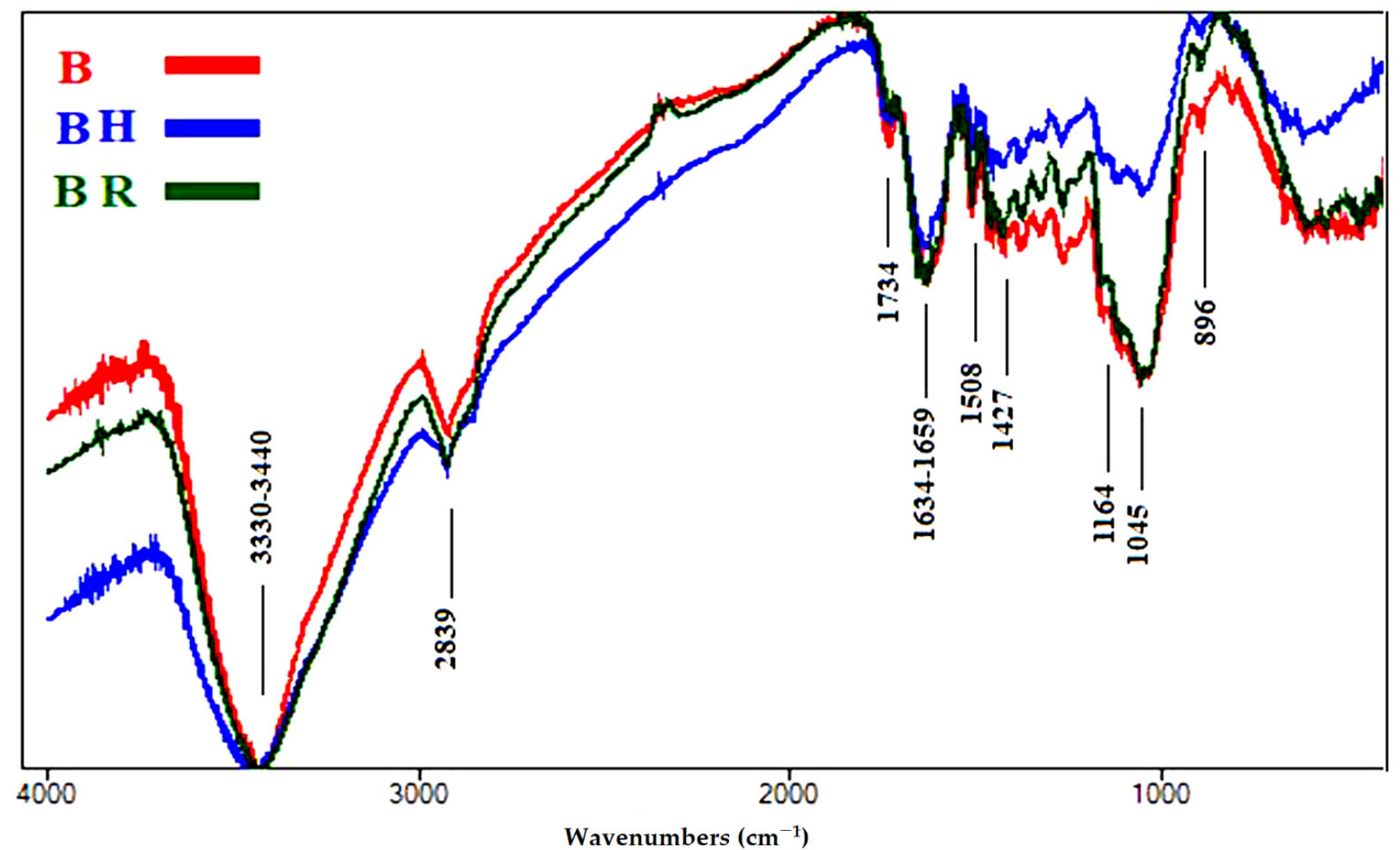

Figure 5. FTIR spectra of the wood samples of Erythrina humeana (B, control; BH, heated ageing; BR, rusted ageing). 


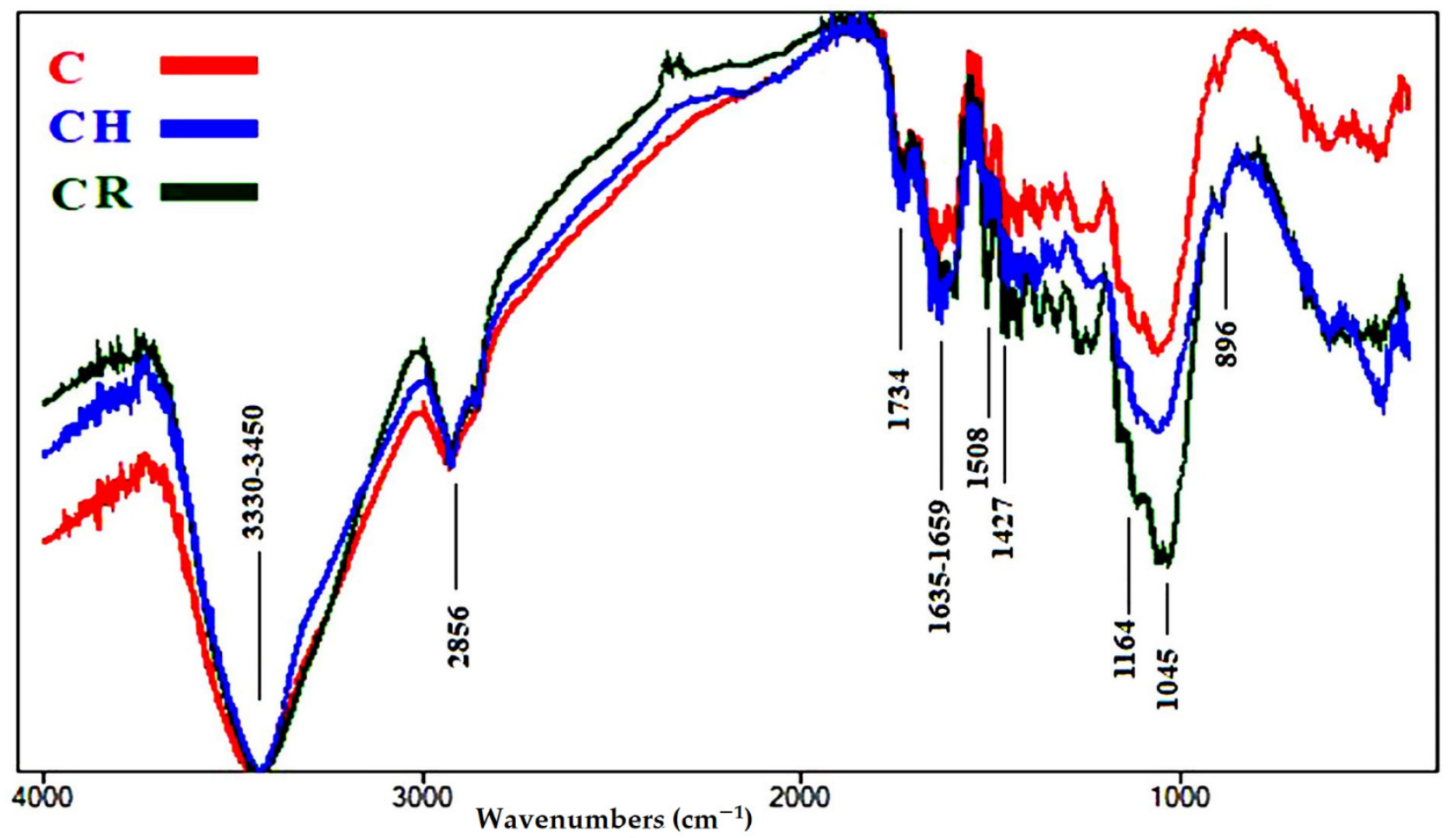

Figure 6. FTIR spectra of the wood sample of Tectona grandis (C, control; $\mathrm{CH}$, heat ageing; $\mathrm{CR}$, rusted ageing).

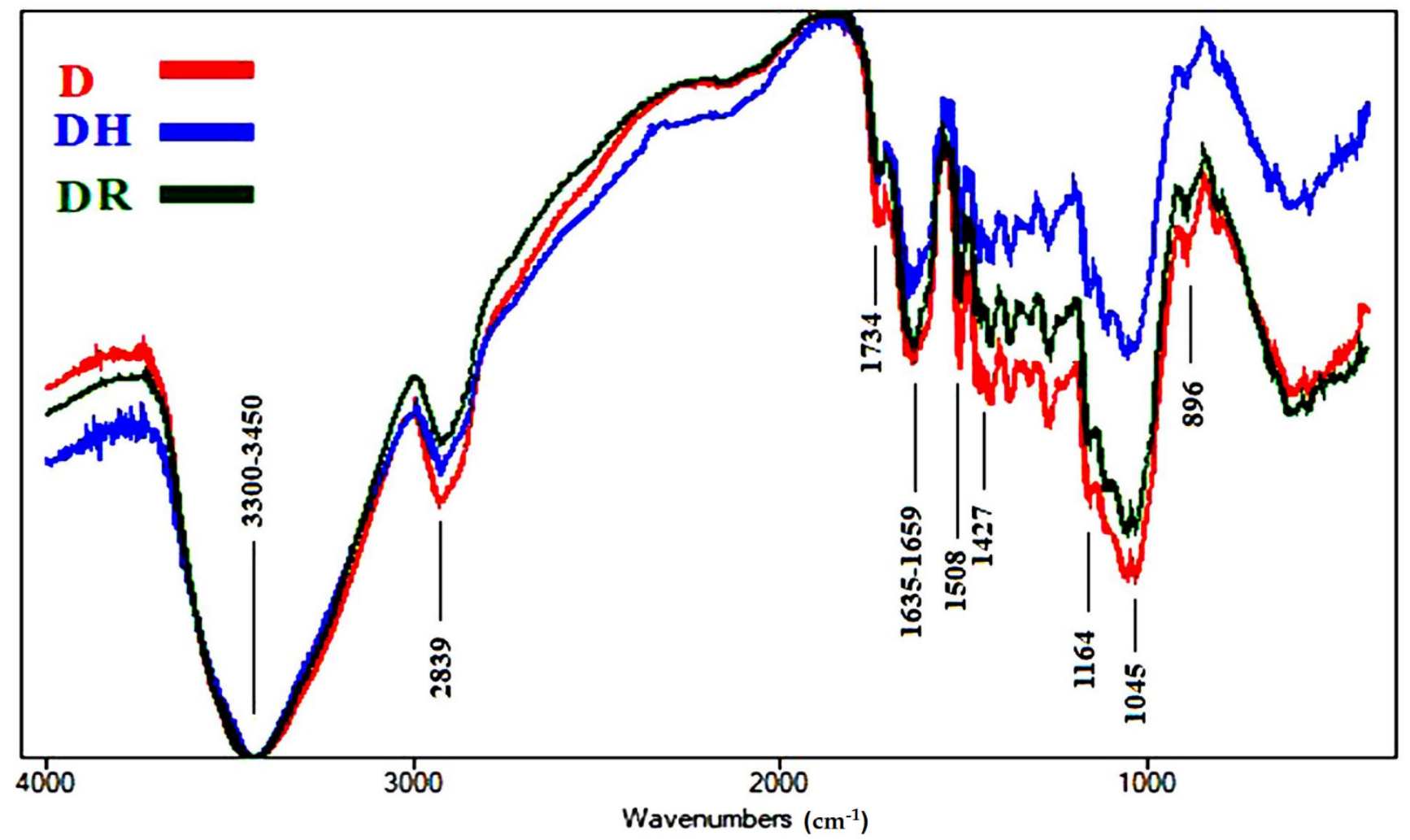

Figure 7. FTIR spectra of the wood samples of Pinus rigida (D, control; DH, heated ageing; DR, rusted ageing). 


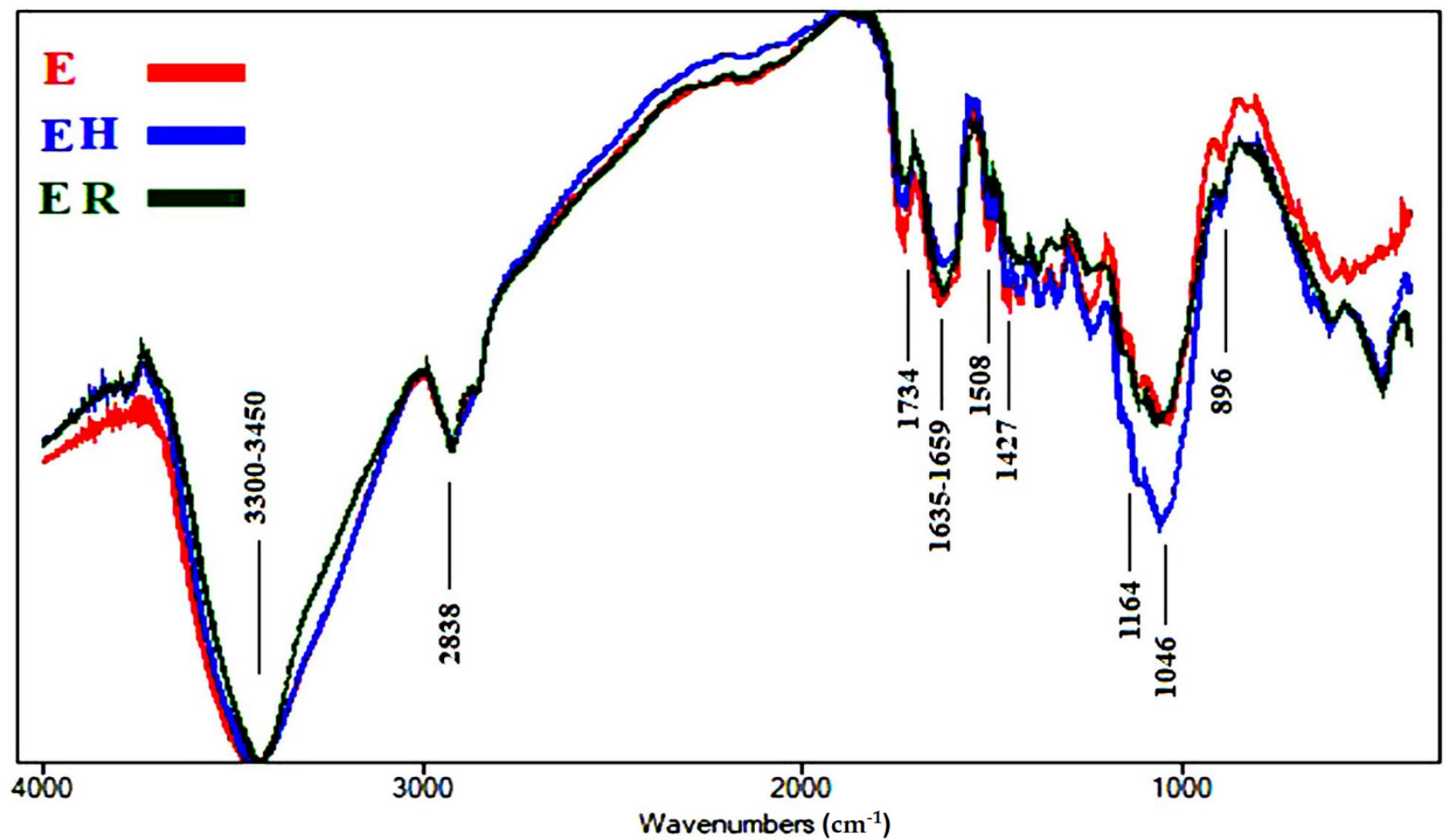

Figure 8. FTIR spectra of the wood sample of Juglans nigra (E, control; EH, heated ageing; ER, rusted ageing).

Current FTIR spectroscopic studies mostly deal with the structure of wood after diverse modifications. Chemical changes in the molecular structure of wood exposed to natural or artificial weathering have been monitored with various FTIR techniques; besides, IR spectroscopy was exercised to reveal thermal modifications in wood and lignin [68].

Table 4. Basic functional groups and their wavenumbers in natural wood.

\begin{tabular}{ccc}
\hline Wavenumbers $\left(\mathbf{c m}^{-\mathbf{1}}\right)^{*}$ & Functional Group Bands & Assignment \\
\hline 3461 & OH stretching & Cellulose, lignin and hemicellulose \\
\hline $2821-2953$ & $\mathrm{CH}_{2}$ stretching & Cellulose, lignin and hemicellulose \\
\hline 1734 & Unconjugated $\mathrm{C}=\mathrm{O}$ stretching & Hemicellulose \\
\hline $1632-1658$ & Conjugated $\mathrm{C}=\mathrm{O}$ stretching $+\mathrm{H}-\mathrm{O}-\mathrm{H}$ absorption & Due to oxidation of cellulose \\
\hline 1507 & $\mathrm{C}=\mathrm{C}$ stretching of the aromatic ring & Lignin \\
\hline 1428 & $\mathrm{CH}_{2}$ bending & Cellulose (crystallized and amorphous) \\
\hline 1164 & O-C-O stretching & Cellulose polymerization \\
\hline 1044 & C-O stretching & Cellulose, lignin and hemicellulose \\
\hline 898 & O-C-O stretching & Crystallized cellulose
\end{tabular}

* Data according to previously published works [69-80].

Figure 4 shows the FTIR spectra of the wood sample from S. terebinthifolius, where a few changes occurred. The $\mathrm{O}-\mathrm{H}$ stretching intensity at $3300-3450 \mathrm{~cm}^{-1}$ was almost negligible in all three samples treated; we observed a slight decrease in unconjugated $\mathrm{C}=\mathrm{O}$ stretching broadening at $1734 \mathrm{~cm}^{-1}$ for hemicellulose in the rusted sample (AR) and a decrease in it in the heated sample $(\mathrm{AH})$. No changes occurred in conjugated $\mathrm{C}=\mathrm{O}$ stretching broadening at $1638-1658 \mathrm{~cm}^{-1}$, which expressed the oxidation of cellulose, in none of the samples. No changes occurred in $C=C$ stretching broadening at $1507 \mathrm{~cm}^{-1}$, related to lignin, in $\mathrm{AH}$, compared with the control (A), while there was a clear decrease in intensity 
in AR. No changes occurred in $\mathrm{CH}_{2}$ bending at $1428 \mathrm{~cm}^{-1}$, related to cellulose (crystallized and amorphous), in none of the samples. A slight decrease in O-C-O stretching broadening at $1164 \mathrm{~cm}^{-1}$, which expressed the polymerization of cellulose, was noted in AR, while there was a clear increase in intensity in $\mathrm{AH}$. No changes occurred in O-C-O stretching at $898 \mathrm{~cm}^{-1}$, related to crystallized cellulose, in none of the samples. The decrease in lignin in $\mathrm{AH}$ indicates an expected decrease in mechanical compressive strength.

Figure 5 shows the FTIR spectra of the wood samples of E. humeana, where slight changes occurred. A slight increase in O-H stretching broadening at $3330-3440 \mathrm{~cm}^{-1}$ in the rusted sample (BR) was found, while there was a clear increase in broadening in the heated sample $(\mathrm{BH})$. A slight decrease in unconjugated $\mathrm{C}=\mathrm{O}$ stretching broadening at $1734 \mathrm{~cm}^{-1}$, which expressed hemicellulose, was noted in all samples. No changes occurred in conjugated $\mathrm{C}=\mathrm{O}$ stretching broadening at $1635-1659 \mathrm{~cm}^{-1}$, related to cellulose oxidation, in $B R$, while there was a slight decrease in intensity in $\mathrm{BH}$. No changes occurred in $\mathrm{C}=\mathrm{C}$ stretching broadening at $1508 \mathrm{~cm}^{-1}$, related to lignin, in $\mathrm{BR}$, compared with the control (B), while there was a clear decrease in intensity in $\mathrm{BH}$. No changes occurred in $\mathrm{CH}_{2}$ bending at $1427 \mathrm{~cm}^{-1}$, which expressed cellulose (crystallized and amorphous), in BR, compared with $\mathrm{B}$, while there was a clear decrease in intensity in $\mathrm{BH}$. A slight decrease in O-C-O stretching broadening at $1164 \mathrm{~cm}^{-1}$, expressing cellulose polymerization, was recorded in $\mathrm{BR}$, while there was a clear decrease in intensity in $\mathrm{BH}$. No changes occurred in O-C-O stretching at $896 \mathrm{~cm}^{-1}$, which expressed crystallized cellulose, in none of the samples. The decrease in lignin in $\mathrm{BH}$ indicates an expected decrease in mechanical compressive strength. Increasing the water content in the wood samples affected the static bending strength in the treated wood samples, especially in BR.

Figure 6 shows the FTIR spectra of the wood sample of T. grandis, where a few changes occurred. The $\mathrm{O}-\mathrm{H}$ stretching intensity at $3300-3450 \mathrm{~cm}^{-1}$ was almost negligible in all three samples. No changes occurred in unconjugated $\mathrm{C}=\mathrm{O}$ stretching broadening at $1734 \mathrm{~cm}^{-1}$, related to hemicellulose, in none of the samples. A slight increase was observed in conjugated $\mathrm{C}=\mathrm{O}$ stretching broadening at $1635-1659 \mathrm{~cm}^{-1}$, for cellulose oxidation, in the rusted sample $(\mathrm{CR})$ and in the heated sample $(\mathrm{CH})$, compared with the control (C). No changes occurred in $C=C$ stretching broadening at $1508 \mathrm{~cm}^{-1}$, for lignin, in none of the samples. No changes occurred in $\mathrm{CH}_{2}$ bending at $1427 \mathrm{~cm}^{-1}$, for cellulose (crystallized and amorphous), in none of the samples. A slight increase in O-C-O stretching broadening at $1164 \mathrm{~cm}^{-1}$, related to cellulose polymerization, was noted in CR, while there was a clear increase in intensity in $\mathrm{CH}$. No changes occurred in O-C-O stretching at $896 \mathrm{~cm}^{-1}$, related to crystallized cellulose, in none of the samples. Increased oxidation of cellulose in the treated samples indicates a change in static bending strength.

Figure 7 shows the FTIR spectra of the wood samples of $P$. rigida, where slight changes occurred. The O-H stretching intensity at $3300-3450 \mathrm{~cm}^{-1}$ was almost negligible in all three samples. We observed a slight decrease in unconjugated $\mathrm{C}=\mathrm{O}$ stretching broadening at $1734 \mathrm{~cm}^{-1}$, which expressed hemicellulose, in all samples. No changes occurred in conjugated $\mathrm{C}=\mathrm{O}$ stretching broadening at $1635-1659 \mathrm{~cm}^{-1}$, related to cellulose oxidation, in the rusted sample (DR), while there was a clear decrease in intensity in the heated sample $(\mathrm{DH})$, compared with the control (D). We observed a slight decrease in intensity in $\mathrm{C}=\mathrm{C}$ stretching broadening at $1508 \mathrm{~cm}^{-1}$ expressing lignin in all samples. No changes occurred in $\mathrm{CH}_{2}$ bending at $1427 \mathrm{~cm}^{-1}$, for cellulose (crystallized and amorphous), in none of the samples. We observed a slight decrease in O-C-O stretching broadening at $1164 \mathrm{~cm}^{-1}$, related to cellulose polymerization, in DR, while there was a clear decrease in intensity in DH. No changes occurred in O-C-O stretching at $896 \mathrm{~cm}^{-1}$, for crystallized cellulose, in DR, while there was a clear decrease in intensity in $\mathrm{DH}$. The decrease in lignin in the treated samples indicates a decrease in the strength of mechanical pressure. An increase in the intensity of the spectra of the functional groups of cellulose in DH indicates an increase in the content of cellulose compared with other chemical compounds.

Figure 8 shows the FTIR spectra of the wood samples of J. nigra, where slight changes occurred. The O-H stretching intensity at $3300-3450 \mathrm{~cm}^{-1}$ was almost negligible in all three 
samples. We observed a slight decrease in unconjugated $\mathrm{C}=\mathrm{O}$ stretching broadening at $1734 \mathrm{~cm}^{-1}$, which expressed hemicellulose, in the heated sample (EH), while there was a clear decrease in intensity in the rusted sample (ER), compared with the control (E). No changes occurred in conjugated $\mathrm{C}=\mathrm{O}$ stretching broadening at $1635-1659 \mathrm{~cm}^{-1}$, related to cellulose oxidation, in ER, while there was a slight decrease in intensity in $\mathrm{EH}$, compared with $\mathrm{E}$. A slight decrease in intensity in $\mathrm{C}=\mathrm{C}$ stretching broadening at $1508 \mathrm{~cm}^{-1}$, related to lignin, was found in all samples. No changes occurred in $\mathrm{CH}_{2}$ bending at $1427 \mathrm{~cm}^{-1}$, related to cellulose (crystallized and amorphous), in $\mathrm{EH}$, while there was a slight decrease in intensity in ER, compared with the control E. No changes occurred in O-C-O stretching broadening at $1164 \mathrm{~cm}^{-1}$, related to cellulose polymerization, in ER, while there was a clear increase in intensity in EH. No changes occurred in O-C-O stretching at $896 \mathrm{~cm}^{-1}$, related to crystallized cellulose, in none of the samples. The decrease in lignin in the treated samples indicates a decrease in the strength of mechanical pressure.

Wood is an anisotropic material and its decomposition is a complex process. It may be difficult to distinguish and modulate the thermal decomposition behavior of each specific component due to the complexity of wood growth. This causes variance in components' content, crystal structure and chemical composition from one species to another [81]. Previous FTIR studies showed that lignin is partially oxidized when wood is situated under dry-air conditions during a long period, causing an increase in the relative proportion of carbonyl groups. However, wood under anoxic conditions may undergo hydrolysis followed by leaching of the hydrophilic carbohydrates, contributing to the dominance of the lignin proportion $[78,82]$. In addition, a high degree of degradation of archeological wood was found, where the average lignin content increased from $25 \%$ in fresh wood to up to $45 \%$ in archeological wood [83].

The obtained results are very similar to the results of some previous research studies, especially with regard to the effect of thermal ageing and its relationship to the mechanical properties of wood samples [84]. During the heat treatment of wood, cellulose was heavily degraded both in commercial and laboratory heat-treated wood samples, probably due to low $\mathrm{pH}$ caused by the heat treatment $[85,86]$. The decrease in cellulose length in unbuffered systems is of such an extent that it may affect the strength properties of the treated wood [87]. Therefore, the hydrothermal treatment should be performed from neutral to alkaline conditions to avoid cellulose degradation in the wood.

\subsubsection{Visual Observation of Inoculated Wood Samples after 7-14 Days}

The effects of ageing on five types of wood against four mold fungi were assessed and compared with the control samples and the visual observations of the growth are presented in Figure 9. No inhibition zones appeared after 14 days of fungal growth of none of the four tested fungi. This is evidence of the lack of influence of accelerated-ageing conditions on the biological resistance of the tested wood samples.

Several studies have discussed the role of metals in general and iron in particular in fungal growth. Iron is one of the most abundant elements on Earth $[22,23,27,28,88]$. It is required by most living systems and it is an essential element for the growth and development of all living organisms. It is essential to the growth and proliferation of the vast majority of microorganisms. This essentiality derives from the role that iron, in its biochemically accessible valence states, plays in a wide variety of electron transfer processes.

For all fungal pathogens, iron is essential for many metabolic processes and the most intelligent and complex systems of iron acquisition from host cells and tissues is found among various fungal strains [89-91]. Iron is highly toxic for biologic substrates, due to its high oxidative potential and its ability to generate reactive oxygen species (ROS) [22]. Fungi can solubilize minerals and metal compounds through several mechanisms, including acidolysis, complexolysis, redoxolysis and by metal accumulation in the biomass. Organic acid excretion by fungi is inter- and intera-specific and can be strongly influenced by the presence of toxic metals [92]. The corrosion reactions can be influenced by microbial activities, especially when the organisms are in close contact with the metal surface, forming 
a biofilm. The resulting metal deterioration is known as biocorrosion, or microbially influenced corrosion [88].

In wood decay, the cellulose in wood is consumed by organisms until it loses its strength. Wood deterioration can be prevented by impregnation with toxic salts that inhibit fungal growth [93]. Many different terms have been used to describe corrosion caused or induced by microbes, including biocorrosion, microbial corrosion and microbiologically influenced/induced corrosion (MIC). Biocorrosion and microbial corrosion tend to hint that the microbes are the main cause of the corrosion, while MIC suggests an involvement of microbes that may or may not be direct [94].
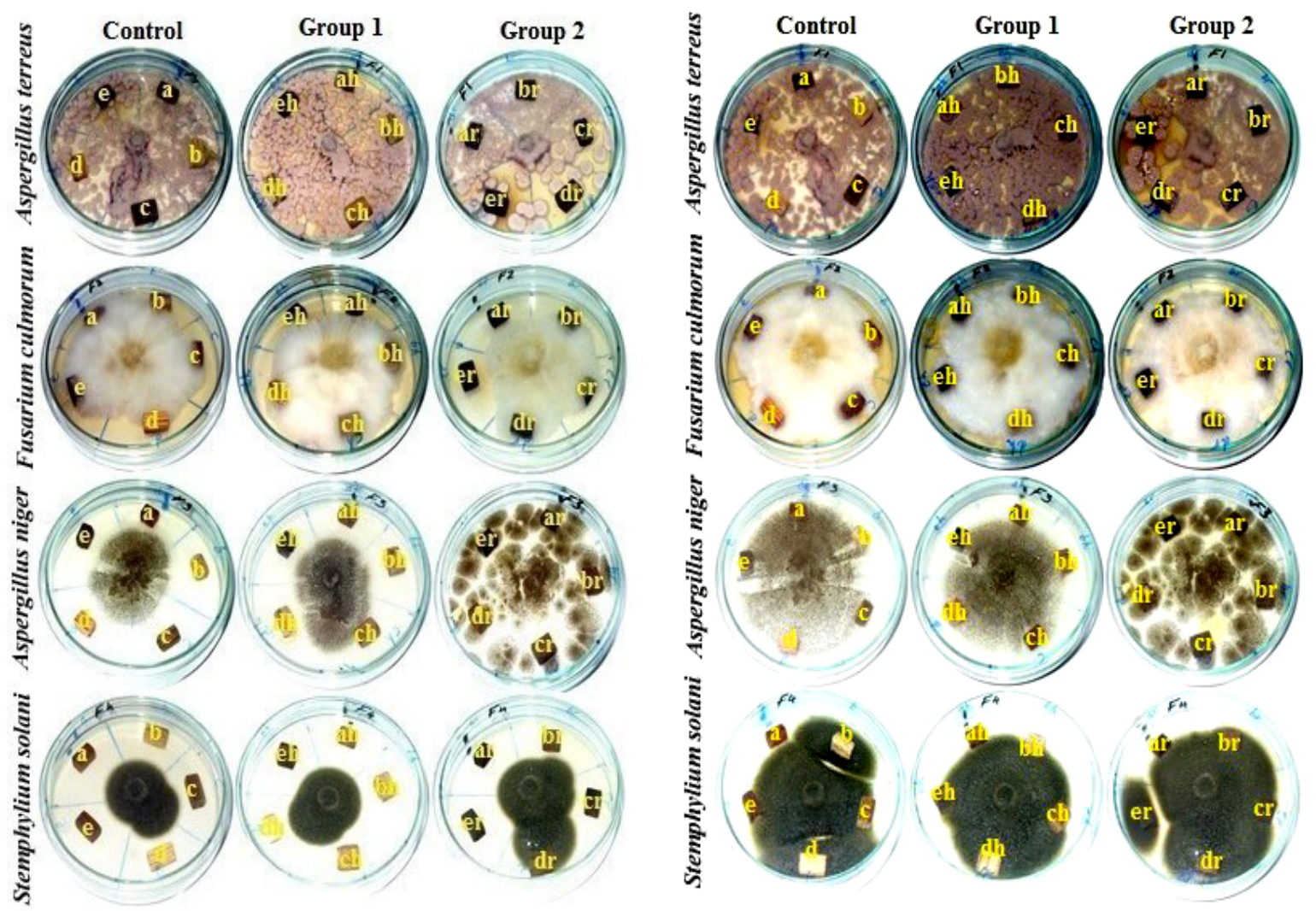

Figure 9. Effects of ageing on five types of wood against four mold fungi.

\subsection{Pulp Properties}

\subsubsection{Yield, Kappa Number and Alkali Residue of Pulps}

The yield, Kappa number and alkali residue of pulps obtained from the studied wood samples and their treatments are shown in Table 5. P. rigida wood showed that the highest pulp yield (\%) was obtained from the untreated wood $(44.33 \%)$, iron-rusted samples $(43.56 \%)$ and heated samples $(41.33 \%)$, followed by the untreated wood from E. humeana (39.66\%), J. nigra (39.56\%), T. grandis (39.46\%) and S. terebinthifolius (39.4\%), while the lowest pulp yield was observed in the heated wood from T. grandis $(34.63 \%)$. In addition, it can be observed that, out of all the woods, the wood samples treated by heating showed a decrease in the pulp yield.

For the Kappa number, the highest number was measured in the pulp of untreated wood from S. terebinthifolius (33.66), followed by P. rigida (29.66), while the lowest number was measured in the pulp of T. grandis heated wood (21.66) and rusted wood (18.33). The residual alkali $(\mathrm{g} / \mathrm{L})$ showed the highest concentration in the pulp produced from the untreated woods of E. humeana $(32.43 \mathrm{~g} / \mathrm{L})$, followed by T. grandis $(28.66 \mathrm{~g} / \mathrm{L})$, while the lowest concentrations were observed in the pulps of rusted $S$. terebinthifolius wood $(13.50 \mathrm{~g} / \mathrm{L})$ and heated wood $(15.46)$ and of the rusted wood of P. rigida $(15.53 \mathrm{~g} / \mathrm{L})$. In 
addition, it can be noticed that the residual alkali concentrations were decreased in the pulps of heated woods and the lowest values were observed in iron-rusted woods.

Table 5. Pulp properties from the studied wood samples.

\begin{tabular}{|c|c|c|c|c|}
\hline Species & Treatment & Pulp Yield (\%) & Kappa Number & Residual Alkali (g/L) \\
\hline \multirow{3}{*}{ Tectona grandis } & Control & $39.46 \pm 0.11^{\mathrm{DE}}$ & $23.33 \pm 0.57^{\mathrm{GH}}$ & $28.66 \pm 1.52^{\mathrm{B}}$ \\
\hline & Heated & $34.63 \pm 0.05^{\mathrm{J}}$ & $21.66 \pm 1.15^{\mathrm{H}}$ & $25.66 \pm 0.57^{\mathrm{D}}$ \\
\hline & Rusted & $36.66 \pm 0.57^{\mathrm{I}}$ & $18.33 \pm 0.57^{\mathrm{I}}$ & $19.66 \pm 0.57^{\mathrm{F}}$ \\
\hline \multirow{3}{*}{ Schinus terebinthifolius } & Control & $39.4 \pm 0.1^{\mathrm{DE}}$ & $33.66 \pm 0.57^{\mathrm{A}}$ & $18.43 \pm 0.11^{\mathrm{H}}$ \\
\hline & Heated & $36.23 \pm 0.11^{\mathrm{I}}$ & $28.33 \pm 1.15^{\mathrm{BC}}$ & $15.46 \pm 0.05 \mathrm{~J}$ \\
\hline & Rusted & $38.83 \pm 0.05^{\mathrm{EF}}$ & $28.33 \pm 0.57^{\mathrm{BC}}$ & $13.50 \pm 0.10^{\mathrm{K}}$ \\
\hline \multirow{3}{*}{ Erythrina humeana } & Control & $39.66 \pm 0.57^{\mathrm{D}}$ & $27.66 \pm 1.15^{C D}$ & $32.43 \pm 0.15^{\mathrm{A}}$ \\
\hline & Heated & $37.56 \pm 0.05 \mathrm{GH}$ & $26 \pm 1 \mathrm{DE}$ & $23.46 \pm 0.05^{\mathrm{E}}$ \\
\hline & Rusted & $38.33 \pm 1.15^{\mathrm{F}}$ & $25.66 \pm 1.52 \mathrm{EF}$ & $18.86 \pm 0.057^{\mathrm{F}-\mathrm{H}}$ \\
\hline \multirow{3}{*}{ Pinus rigida } & Control & $44.33 \pm 0.57^{\mathrm{A}}$ & $29.66 \pm 0.57^{\mathrm{B}}$ & $27.3 \pm 0.1^{\mathrm{C}}$ \\
\hline & Heated & $41.33 \pm 0.57^{\mathrm{C}}$ & $28 b \pm 1^{C}$ & $18.6 \pm 0.2^{\mathrm{GH}}$ \\
\hline & Rusted & $43.56 \pm 0.11^{\mathrm{B}}$ & $26 \pm 2^{\mathrm{DE}}$ & $15.53 \pm 0.02 \mathrm{~J}$ \\
\hline \multirow{3}{*}{ Juglans nigra } & Control & $39.56 \pm 0.15^{\mathrm{D}}$ & $26.66 c \pm 0.57 \mathrm{DE}$ & $27.33 \pm 1.15^{\mathrm{C}}$ \\
\hline & Heated & $37.4 \pm 0.10^{\mathrm{H}}$ & $24 \pm 2^{\mathrm{FG}}$ & $19.46 \pm 0.11^{\mathrm{FD}}$ \\
\hline & Rusted & $38.16 \pm 0.11^{\text {FG }}$ & $22.66 \pm 0.57^{\mathrm{GH}}$ & $17 \pm 1^{\mathrm{I}}$ \\
\hline \multicolumn{2}{|c|}{$p$-value } & $<0.0001$ & 0.0373 & $<0.0001$ \\
\hline
\end{tabular}

Means with the same letter/s within the same column are not significantly different according to LSD0.05.

\subsubsection{Mechanical and Optical Properties of Handsheets}

The mechanical and physical properties of the handsheets produced from the studied woods and their treatments (heated and iron-rusted) are shown in Table 6. The highest significant values of tensile strength were observed in pulp paper produced from the untreated, heated and iron-rusted wood of P. rigida, with values of $69.66,65.66$ and $68.33 \mathrm{Nm} / \mathrm{g}$, respectively, while the lowest values were found for the handsheets produced from the pulp of the heated woods of J. nigra $(40.82 \mathrm{Nm} / \mathrm{g})$ and E. humeana $(40.33 \mathrm{Nm} / \mathrm{g})$ and of J. nigra rusted wood $(42.56 \mathrm{Nm} / \mathrm{g})$.

We obtained tear resistance values of the handsheets produced from the pulp of woods from untreated P. rigida $\left(8.68 \mathrm{mN} \cdot \mathrm{m}^{2} / \mathrm{g}\right)$, T. grandis $\left(7.83 \mathrm{mN} \cdot \mathrm{m}^{2} / \mathrm{g}\right)$ and rusted P. rigida $\left(7.56 \mathrm{mN} \cdot \mathrm{m}^{2} / \mathrm{g}\right)$; we observed the lowest values in the pulp manufactured from the heated and iron-rusted wood of E. humeana, with values of 2.17 and $2.46 \mathrm{mN} \cdot \mathrm{m}^{2} / \mathrm{g}$, respectively.

The highest burst strength values of the tested paper sheets were reported from the pulp of the untreated woods of P. rigida $\left(8.19 \mathrm{kPa} \cdot \mathrm{m}^{2} / \mathrm{g}\right)$ and $T$. grandis $\left(7.49 \mathrm{kPa} \cdot \mathrm{m}^{2} / \mathrm{g}\right)$, while the lowest values were observed in the handsheets obtained from E. humeana pulps from heated wood $\left(2.14 \mathrm{kPa} \cdot \mathrm{m}^{2} / \mathrm{g}\right)$ and iron-rusted wood $\left(2.6 \mathrm{kPa} \cdot \mathrm{m}^{2} / \mathrm{g}\right)$.

The highest fold numbers were reported in the examined handsheets produced from the pulp of the untreated, heated and rusted wood from P. rigida, with 195.66, 186.33 and 185.66, respectively, followed by T. grandis, with $114.66,102.33$ and 105.33, respectively, while the lowest fold numbers were reported from the pulp produced from untreated, heated and rusted S. terebinthifolius woods with values of $9.66,8.33$ and 8.66 , respectively.

The highest brightness percentages were found in the handsheets produced from untreated, rusted and heated J. nigra wood pulp with values of $38.66,35.33 \%$ and $31.33 \%$, respectively, while the lowest percentages were found in the examined handsheets produced from untreated, heated and rusted wood pulp obtained from T. grandis with percentages of $18.33 \%, 15.33 \%$ and $16.33 \%$, respectively. 
For the opacity (\%), the highest values of 83.66 and $82.66 \%$, were observed in the tested handsheets obtained from the pulp of heated and rusted wood of T. grandis, respectively, followed by the rusted wood of S. terebinthifolius $(76.66 \%)$, while the lowest value was found in the handsheets produced from untreated J. nigra wood pulp (55.3\%). The grammage for all the studied wood materials ranged between 60.13 and $60.23 \mathrm{~g} / \mathrm{m}^{2}$.

Table 6. Mechanical and optical properties of handsheets produced from heated or rusted wood pulp compared to untreated control.

\begin{tabular}{|c|c|c|c|c|c|c|c|c|}
\hline \multirow[b]{2}{*}{ Wood species } & \multirow[b]{2}{*}{ Treatment } & \multicolumn{4}{|c|}{ Mechanical Properties } & \multicolumn{2}{|c|}{ Optical Properties } & \multirow[b]{2}{*}{$\begin{array}{c}\text { Grammage } \\
\left(\mathrm{g} / \mathrm{m}^{2}\right)\end{array}$} \\
\hline & & $\begin{array}{l}\text { Tensile } \\
\text { Strength } \\
\text { Nm/g }\end{array}$ & $\begin{array}{c}\text { Tear } \\
\text { Resistance } \\
\mathrm{mN} \cdot \mathrm{m}^{2} / \mathrm{g}\end{array}$ & $\begin{array}{l}\text { Burst Strength } \\
\mathrm{kPa} \cdot \mathrm{m}^{2} / \mathrm{g}\end{array}$ & Fold Number & Brightness (\%) & Opacity (\%) & \\
\hline \multirow{3}{*}{ Tectona grandis } & Control & $57.06 \pm 0.66^{\mathrm{E}}$ & $7.83 \pm 0.58^{\mathrm{B}}$ & $7.49 \pm 0.56^{\mathrm{B}}$ & $114.66 \pm 0.57^{\mathrm{C}}$ & $18.33 \pm 0.57^{\mathrm{I}}$ & $75.66 \pm 0.57^{\mathrm{B}}$ & $60.13 \pm 0.05$ \\
\hline & Heated & $44.56 \pm 0.02^{\mathrm{I}}$ & $4.47 \pm 0.05^{\mathrm{F}}$ & $3.36 \pm 0.02^{\mathrm{F}}$ & $102.33 \pm 1.15^{\mathrm{E}}$ & $15.33 \pm 0.57 \mathrm{~J}$ & $83.66 \pm 0.57^{\mathrm{A}}$ & $60.16 \pm 0.05$ \\
\hline & Rusted & $52.33 \pm 0.57^{\mathrm{F}}$ & $6.23 \pm 0.01^{\mathrm{C}}$ & $4.75 \pm 0.02^{\mathrm{E}}$ & $105.33 \pm 0.57^{\mathrm{D}}$ & $16.33 \pm 0.57^{\mathrm{J}}$ & $82.66 \pm 0.57^{\mathrm{A}}$ & $60.16 \pm 0.05$ \\
\hline \multirow{3}{*}{$\begin{array}{c}\text { Schinus } \\
\text { terebinthifolius }\end{array}$} & Control & $59.66 \pm 0.57^{\mathrm{D}}$ & $5.6 \pm 0.57^{\mathrm{D}}$ & $4.38 \pm 0.57^{\mathrm{E}}$ & $9.66 \pm 0.57^{\mathrm{L}}$ & $29.66 \pm 0.57^{\mathrm{D}}$ & $65.33 \pm 0.57^{\mathrm{EF}}$ & $60.2 \pm 0.1$ \\
\hline & Heated & $50.66 \pm 0.57^{G}$ & $3.25 \pm 0.005^{\mathrm{G}}$ & $3.44 \pm 0.005^{\mathrm{F}}$ & $8.33 \pm 1.15^{\mathrm{L}}$ & $25.33 \pm 0.57^{\mathrm{G}}$ & $72.66 \pm 0.57^{C}$ & $60.16 \pm 0.05$ \\
\hline & Rusted & $56.63 \pm 0.05^{\mathrm{E}}$ & $3.35 \pm 0.01^{G}$ & $3.76 \pm 0.11^{\mathrm{F}}$ & $8.66 \pm 0.57^{\mathrm{L}}$ & $28.66 \pm 0.57^{\mathrm{DE}}$ & $76.66 \pm 1.52^{\mathrm{B}}$ & $60.16 \pm 0.11$ \\
\hline \multirow{3}{*}{$\begin{array}{l}\text { Erythrina } \\
\text { humeana }\end{array}$} & Control & $48.66 \pm 0.57^{\mathrm{H}}$ & $4.63 \pm 0.56^{\mathrm{F}}$ & $4.75 \pm 0.01^{\mathrm{E}}$ & $46 \pm 1^{\mathrm{F}}$ & $27.33 \pm 0.57^{\mathrm{EF}}$ & $62 \pm 1.73^{\mathrm{G}}$ & $60.2 \pm 0.1$ \\
\hline & Heated & $40.33 \pm 0.57^{K}$ & $2.17 \pm 0.011^{\mathrm{H}}$ & $2.14 \pm 0.01^{\mathrm{H}}$ & $38.66 \pm 0.57^{\mathrm{H}}$ & $23.33 \pm 1.52^{\mathrm{H}}$ & $75.33 \pm 1.52^{\mathrm{BC}}$ & $60.20 \pm 0.10$ \\
\hline & Rusted & $44.66 \pm 0.57^{\mathrm{I}}$ & $2.46 \pm 0.11^{\mathrm{H}}$ & $2.6 \pm 0.1^{\mathrm{G}}$ & $42.66 \pm 0.57^{\mathrm{G}}$ & $24.33 \pm 1.15^{\mathrm{HG}}$ & $68.33 \pm 0.57^{\mathrm{D}}$ & $60.20 \pm 0.10$ \\
\hline \multirow{3}{*}{ Pinus rigida } & Control & $69.66 \pm 0.57^{\mathrm{A}}$ & $8.68 \pm 0.58^{\mathrm{A}}$ & $8.19 \pm 0.58^{\mathrm{A}}$ & $195.66 \pm 0.57^{\mathrm{A}}$ & $29.66 \pm 0.57^{\mathrm{D}}$ & $67.66 \pm 1.52^{\mathrm{DE}}$ & $60.23 \pm 0.11$ \\
\hline & Heated & $65.66 \pm 1.52^{C}$ & $6.64 \pm 0.01^{C}$ & $5.34 \pm 0.02^{\mathrm{D}}$ & $186.33 \pm 1.52^{\mathrm{B}}$ & $24.66 \pm 1.52^{\mathrm{HG}}$ & $75.66 \pm 1.52^{\mathrm{B}}$ & $60.23 \pm 0.05$ \\
\hline & Rusted & $68.33 \pm 1.15^{\mathrm{B}}$ & $7.56 \pm 0.15^{\mathrm{B}}$ & $5.85 \pm 0.01^{\mathrm{D}}$ & $185.66 \pm 0.57^{\mathrm{B}}$ & $27 \pm 1^{\mathrm{F}}$ & $74.66 \pm 1.15^{\mathrm{BC}}$ & $60.26 \pm 0.05$ \\
\hline \multirow{3}{*}{ Juglans nigra } & Control & $45.29 \pm 1.16^{\mathrm{I}}$ & $6.54 \pm 0.005^{\mathrm{C}}$ & $5.82 \pm 0.01^{\mathrm{D}}$ & $24.66 \pm 0.57^{\mathrm{I}}$ & $38.66 \pm 0.57^{\mathrm{A}}$ & $55.3 \pm 0.57^{\mathrm{H}}$ & $60.16 \pm 0.05$ \\
\hline & Heated & $40.82 \pm 0.005^{\mathrm{K}}$ & $4.87 \pm 0.02^{\mathrm{EF}}$ & $3.55 \pm 0.02^{\mathrm{F}}$ & $22 \pm 1.73^{\mathrm{J}}$ & $31.33 \pm 0.57^{\mathrm{C}}$ & $63 \pm 1$ FG & $60.2 \pm 0.1$ \\
\hline & Rusted & $42.56 \pm 0.05^{\mathrm{J}}$ & $5.23 \pm 0.01^{\mathrm{DE}}$ & $3.64 \pm 0.005^{\mathrm{F}}$ & $20.33 \pm 1.52^{\mathrm{K}}$ & $35.33 \pm 0.57^{\mathrm{B}}$ & $63 \pm 5.19^{\mathrm{FG}}$ & 60.2 \\
\hline \multicolumn{2}{|c|}{$p$-value } & $<0.0001$ & $<0.0001$ & $<0.0001$ & $<0.0001$ & 0.0028 & $<0.0001$ & 0.9964 \\
\hline
\end{tabular}

Notes: pulp freeness (csf) of all samples at 300 csf. Means with the same letter/s within the same column are not significantly different according to LSD 0.05 .

\section{Conclusions}

The findings of the present work confirm the effects of accelerated ageing induced by iron rusting and heating treatments of five wood species on their mechanical, chemical and fungal activity properties. A significant and noticeable decrease was observed in the values of maximum tensile strength parallel to the grain for all aged wood samples compared to the standard samples (untreated). The maximum crushing-strength values were reported in untreated, heated and rusted T. grandis wood and the lowest values were observed in the tested untreated, heated and rusted E. humeana wood. Through the use of FTIR, we found that the decrease in lignin in the heated sample of $S$. terebinthifolius indicates an expected decrease in mechanical compressive strength, whereas the decrease in lignin in the heated sample of E. humeana indicates an expected decrease in mechanical compressive strength. An increase in the intensity of the spectra of the functional groups of cellulose in the heated samples indicates an increase in the content of cellulose, compared to other chemical compounds. According to the biological activity, it was found that no inhibition zones appeared in any of the tested woods against the fungal growth of none of the four tested fungi. The mechanical and optical properties of the handsheets were estimated. The highest significant values of tensile and burst strengths were observed in the pulp paper produced from the untreated, heated and iron-rusted wood of P. rigida. Accelerating wood ageing in this study via means of heating and iron rusting resulted in significant differences in the mechanical and chemical properties of wood, as well as the mechanical and physical properties of the produced pulp paper.

Author Contributions: Conceptualization, W.A.A.A.E., A.S.T., M.Z.M.S., Y.G.D.F., M.F.M. and R.A.N.; data curation, W.A.A.A.E., A.S.T., M.Z.M.S., Y.G.D.F. and R.A.N.; formal analysis, M.Z.M.S., 
Y.G.D.F., M.F.M. and R.A.N.; funding acquisition, M.B. and V.P.; investigation, W.A.A.A.E., M.B. and V.P.; methodology, W.A.A.A.E., A.S.T., M.Z.M.S., Y.G.D.F., M.F.M. and R.A.N.; project administration, M.Z.M.S.; resources, M.B. and V.P.; software, M.B. and V.P.; validation, A.S.T.; visualization, W.A.A.A.E.; writing一original draft, W.A.A.A.E., A.S.T., M.Z.M.S., Y.G.D.F., M.B., M.F.M., R.A.N. and V.P.; writing-review and editing, W.A.A.A.E., A.S.T., M.Z.M.S., Y.G.D.F., M.B., M.F.M., R.A.N. and V.P. All authors have read and agreed to the published version of the manuscript.

Funding: This research was supported by the Grant Agency of the Faculty of Civil Engineering at Czech Technical University in Prague, under project No. SGS19/143/OHK1/3T/11.

Institutional Review Board Statement: Not applicable.

Informed Consent Statement: Not applicable.

Data Availability Statement: Not applicable.

Conflicts of Interest: The authors declare no conflict of interest.

\section{References}

1. Hamed, S.A.-K.M.; Salem, M.Z.M.; Ali, H.M.; Ahmed, K.M.E.-S. Investigating the impact of weathering and indoor aging on wood acidity using spectroscopic analyses. BioResources 2020, 15, 6506-6525. [CrossRef]

2. Kocaefe, D.; Huang, X.; Kocaefe, Y.; Boluk, Y. Quantitative characterization of chemical degradation of heat-treated wood surfaces during artificial weathering using XPS. Surf. Interface Anal. 2013, 45, 639-649. [CrossRef]

3. Salim, E.; Abdel-Hamied, M.; Salim, S.; Gamal, S.; Mohamed, S.; Galal, F.E.-Z.; Tarek, F.; Hassan, R.R.A.; Ali, H.M.; Salem, M.Z.M. Reduction of borax/agar-based gel residues used to neutralize acidity of a historical manuscript with use of different paper barriers: Artificial ageing results. BioResources 2020, 15, 6576-6599. [CrossRef]

4. Temiz, A.; Terziev, N.; Eikenes, M.; Hafren, J. Effect of accelerated weathering on surface chemistry of modified wood. Appl. Surf. Sci. 2007, 253, 5355-5362. [CrossRef]

5. Temiz, A.; Yildiz, U.C.; Aydin, I.; Eikenes, M.; Alfredsen, G.; Çolakoglu, G. Surface roughness and color characteristics of wood treated with preservatives after accelerated weathering test. Appl. Surf. Sci. 2005, 250, 35-42. [CrossRef]

6. Tshabalala, M.A.; Gangstad, J.E. Accelerated weathering of wood surfaces coated with multifunctional alkoxysilanes by sol-gel deposition. J. Coat. Technol. 2003, 75, 37-43. [CrossRef]

7. Feist, W.C. Outdoor Wood Weathering and Protection. In Archaeological Wood, Properties, Chemistry, and Preservation; American Chemical Society: Washington, DC, USA, 1989; pp. 263-298. [CrossRef]

8. Williams, R.S. Weathering of wood. Handb. Wood Chem. Wood Compos. 2005, 7, 139-185.

9. Schmidt, P.; Porraz, G.; Slodczyk, A.; Bellot-Gurlet, L.; Archer, W.; Miller, C.E. Heat treatment in the South African Middle Stone Age: Temperature induced transformations of silcrete and their technological implications. J. Archaeol. Sci. 2013, 40, 3519-3531. [CrossRef]

10. Popescu, M.C.; Froidevaux, J.; Navi, P.; Popescu, C.M. Structural modifications of Tilia cordata wood during heat treatment investigated by FT-IR and 2D IR correlation spectroscopy. J. Mol. Struct. 2013, 1033, 176-186. [CrossRef]

11. Cakıcıer, N.; Korkut, S.; Korkut, D.; Kurtoğlu, A.; Sönmez, A. Effects of QUV accelerated aging on surface hardness, surface roughness, glossiness, and color difference for some wood species. Int. J. Phys. Sci. 2011, 6, 1929-1939. [CrossRef]

12. Miklečić, J.; Jirouš-Rajković, V. Accelerated Weathering of Coated and Uncoated Beech Wood Modified with Citric Acid. Drv. Ind. 2011, 277-282. [CrossRef]

13. Matsuo, M.; Yokoyama, M.; Umemura, K.; Sugiyama, J.; Kawai, S.; Gril, J.; Kubodera, S.; Mitsutani, T.; Ozaki, H.; Sakamoto, M.; et al. Aging of wood: Analysis of color changes during natural aging and heat treatment. Holzforschung 2011, 65, 361-368. [CrossRef]

14. Akyildiz, M.H.; Saim, A. Effect of Heat Treatment on Equilibrium Moisture Content (EMC) of Some Wood Species in Turkey. Res. J. Agric. Biol. Sci. 2008, 4, 660-665.

15. Baker, A. Degradation of Wood by Products of Metal Corrosion; US Department of Agriculture, Forest Service, Forest Products Laboratory: Washington, DC, USA, 1974; Volume 229.

16. Zelinka, S.L.; Stone, D.S. Corrosion of metals in wood: Comparing the results of a rapid test method with long-term exposure tests across six wood treatments. Corros. Sci. 2011, 53, 1708-1714. [CrossRef]

17. Zelinka, S.; Rammer, D. Review of Test Methods Used to Determine the Corrosion Rate of Metals in Contact with Treated Wood; General Technical Report; FPL-GTR-156; US Department of Agriculture, Forest Service, Forest Products Laboratory: Washington, DC, USA, 2005.

18. Zelinka, S.L. Corrosion of metals in wood products. In Corrosion of Metals in Wood Products, Developments in Corrosion Protection; Aliofkhazraei, M., Ed.; InTech: London, UK, 2014; pp. 567-592, ISBN 978-953-51-1223-5. [CrossRef]

19. Zelinka, S.L.; Glass, S.V.; Derome, D. The effect of moisture content on the corrosion of fasteners embedded in wood subjected to alkaline copper quaternary treatment. Corros. Sci. 2014, 83, 67-74. [CrossRef] 
20. Zelinka, S.L.; Stone, D.S. The effect of tannins and $\mathrm{pH}$ on the corrosion of steel in wood extracts. Mater. Corros. 2011, 62, 739-744. [CrossRef]

21. Zelinka, S.L. Corrosion of Fasteners in Wood Treated with Newer Wood Preservatives; General Technical Report, FPL-GTR-220; USDA Forest Service, Forest Products Laboratory: Washington, DC, USA, 2013; 68p. [CrossRef]

22. Symeonidis, A.; Marangos, M. Iron and microbial growth. In Insight and Control of Infectious Disease in Global Scenario; InTech: London, UK, 2012; pp. 289-330.

23. Kosman, D.J. Molecular mechanisms of iron uptake in fungi. Mol. Microbiol. 2003, 47, 1185-1197. [CrossRef] [PubMed]

24. Hirayama, T. Fluorescent probes for the detection of catalytic Fe(II) ion. Free Radic. Biol. Med. 2019, 133, 38-45. [CrossRef]

25. Nyilasi, I.; Papp, T.; Takó, M.; Nagy, E.; Vágvölgyi, C. Iron Gathering of Opportunistic Pathogenic Fungi. A Mini Review. Acta Microbiol. Immunol. Hung. 2005, 52, 185-197. [CrossRef]

26. Xu, G.; Goodell, B. Mechanisms of wood degradation by brown-rot fungi: Chelator-mediated cellulose degradation and binding of iron by cellulose. J. Biotechnol. 2001, 87, 43-57. [CrossRef]

27. Potrykus, J.; Stead, D.; Maccallum, D.M.; Urgast, D.S.; Raab, A.; Van Rooijen, N.; Feldmann, J.; Brown, A.J.P. Fungal Iron Availability during Deep Seated Candidiasis Is Defined by a Complex Interplay Involving Systemic and Local Events. PLoS Pathog. 2013, 9, e1003676. [CrossRef]

28. Howard, D.H. Acquisition, Transport, and Storage of Iron by Pathogenic Fungi. Clin. Microbiol. Rev. 1999, 12, 394-404. [CrossRef]

29. Salem, M.Z.M.; Alotaibi, S.; Abo Elgat, W.A.A.; Taha, A.; Fares, Y.; El-Shehawi, A.; Ghareeb, R. Antifungal Activities of Wood and Non-Wood Kraft Handsheets Treated with Melia azedarach Extract Using SEM and HPLC Analyses. Polymers 2021, 13, 2012. [CrossRef]

30. Salem, M.Z.M.; Ali, H.M.; Akrami, M. Moringa oleifera seeds-removed ripened pods as alternative for papersheet production: Antimicrobial activity and their phytoconstituents profile using HPLC. Sci. Rep. 2021, 11, 19027. [CrossRef] [PubMed]

31. Taha, A.S.; Abo Elgat, W.A.A.; Fares, Y.G.D.; Dessoky, E.S.; Behiry, S.I.; Salem, M.Z.M. Using plant extractives as eco-friendly pulp additives: Mechanical and antifungal properties of paper sheets made from linen fibers. BioResources 2021, 16, 2589-2606. [CrossRef]

32. Strlič, M.; Grossi, C.M.; Dillon, C.; Bell, N.; Fouseki, K.; Brimblecombe, P.; Menart, E.; Ntanos, K.; Lindsay, W.; Thickett, D.; et al. Damage function for historic paper. Part III: Isochrones and demography of collections. Heritage Sci. 2015, 3, 40. [CrossRef]

33. Hassan, R.R.A.; Mahmoud, S.M.A.; Karam, Y.A.; Salah, S.M.; Ebrahim, S.Y.; Abdelwahab, M.A.; Ahmed, A.-H.M.H.; Ali, H.M.; Böhm, M.; Salem, M.Z.M. Application of Frankincense and Rice Starch as Eco-Friendly Substances for the Resizing of Paper as a Conservation Practice. BioResources 2021, 16, 7180-7204. [CrossRef]

34. Rebrikova, N.L.; Manturovskaya, N.V. Foxing-A New Approach to an Old Problem. Restaurator 2000, 21, 85-100. [CrossRef]

35. Ghorbani, M.; Samanian, K.; Afsharpuor, M. Effect of physical properties of bacterial cellulose nanofibers bio-composite as a coating on the paper works. Int. J. Conserv. Sci. 2018, 9, 71-80.

36. Baglioni, P.; Giorgi, R. Soft and hard nanomaterials for restoration and conservation of cultural heritage. Soft Matter 2006, 2, 293-303. [CrossRef] [PubMed]

37. Budakçi, M.; Korkut, D.S. The color changes on varnish layers after accelerated aging through the hot and cold-check test. Afr. J. Biotechnol. 2010, 9, 3595-3602.

38. Froidevaux, J.; Volkmer, T.; Gril, J.; Fioravanti, M.; Navi, P. Comparison between accelerated thermo-hydro aged wood and naturally aged wood. In Proceedings of the 1st Workshop of COST Action FP0904'Mechano-Chemical Transformations of Wood during Thermo-Hydro-Mechanical Processing, Bienne, Switzerland, 16 February 2011.

39. Altinok, M.; Ozalp, M.; Korkut, S. The effects of heat treatment on some mechanical properties of laminated beech (Fagus orientalis L.) wood. Wood Res. 2010, 55, 131-142.

40. Matsuo, M.; Yokoyama, M.; Umemura, K.; Sugiyama, J.; Kawai, S.; Gril, J.; Yano, K.I.; Kubodera, S.; Mitsutani, T.; Ozaki, H. Evaluation of the aging wood from historical buildings as compared with the accelerated aging wood and cellulose, Analysis of color properties. In Proceedings of the International Conference on Wooden Cultural Heritage, Evaluation of Deterioration and Management of Change, Hamburg, Germany, 7-10 October 2009; p. 6.

41. Yokoyama, M.; Gril, J.; Matsuo, M.; Yano, H.; Sugiyama, J.; Clair, B.; Kubodera, S.; Mistutani, T.; Sakamoto, M.; Ozaki, H. Mechanical characteristics of aged Hinoki (Chamaecyparis obtusa Endl.) wood from Japanese historical buildings. In Proceedings of the International Conference on Wooden Cultural Heritage, Evaluation of Deterioration and Management of Change, Hamburg, Germany, 7-10 October 2009; p. 8.

42. Colmars, J.; Gril, J.; Yano, H.; Nakano, T. Creep Properties of Heat Treated Wood in Radial Direction. In Proceedings of the Joint meeting of COST Action IE0601 WoodCultHer Wood Science for Conservation of Cultural Heritage, and the European Society of Wood Mechanics, Braga, Portugal, 5-7 November 2008; pp. 24-29.

43. American Wood Preservers' Association. Standard Method of Determining Corrosion of Metal in Contact with Treated Wood; AWPA E12-94; American Wood Preservers' Association: Selma, AL, USA, 2014.

44. American Society for Testing and Materials. Standard Practice for Operating Salt Spray (Fog) Apparatus; ASTM, B-117-03; American Society for Testing and Materials: West Conshohocken, PA, USA, 2003.

45. McNatt, J.D.; Link, C.L. Analysis of ASTM D 1037 accelerated-aging test. For. Prod. J. 1989, 39, 51-57.

46. American Society for Testing and Materials. Standard Test Methods for Evaluating Properties of Wood-Based Fiber and Particle Panel Materials; ASTM, Designation: D 1037-06A; American Society for Testing and Materials: West Conshohocken, PA, USA, 2006. 
47. Nasser, R.A.; Salem, M.Z.M.; Al-Mefarrej, H.A.; Aref, I.M. Measurement of Some Strength Properties and the Chemical Compositions of Seven Hardwood Species Grown in Northwest Egypt. J. Test. Eval. 2016, 44, 20140532. [CrossRef]

48. British Standard Methods of Testing Small Clear Specimens of Timber. London, UK. Available online: http:/ /211.167.243.154: 1012/file/gwbz/BS $\backslash$ T1 \th373-1957.pdf (accessed on 18 September 2021).

49. Bektaş, İ.; Ramazan, K. Principal mechanical properties of cypress wood (Cupressus Sempervirens L.) naturally grown in (Kahramanmaraş) Eastern Mediterranean of Turkey. Gazi Univ. J. Sci. 2010, 23, 357-362.

50. Korkut, S.; Guller, B. Physical and mechanical properties of European Hophornbeam (Ostrya carpinifolia Scop.) wood. Bioresour. Technol. 2008, 99, 4780-4785. [CrossRef] [PubMed]

51. Zeidler, A.; Salem, M.Z.M.; Borůvka, V. Mechanical Properties of Grand Fir Wood Grown in the Czech Republic in Vertical and Horizontal Positions. BioResources 2015, 10, 793-808. [CrossRef]

52. American Society for Testing and Materials (ASTM). D143-14. Standard Test Methods for Small Clear Specimens of Timber; ASTM International: West Conshohocken, PA, USA, 2014.

53. El-Osta, M. Some strength properties of Juniper southwest Saudi Arabia. J. Coll. Agric. King Saud. Univ. 1985, 7, $103-112$.

54. American Society for Testing and Materials (ASTM). D2395-84: Standard Test Method for Specific Gravity of Wood and Wood-Base Materials-Method A; ASTM International: West Conshohocken, PA, USA, 1989.

55. Salem, M.Z.M.; Elgat, W.A.A.A.; Taha, A.S.; Fares, Y.G.D.; Ali, H.M. Impact of Three Natural Oily Extracts as Pulp Additives on the Mechanical, Optical, and Antifungal Properties of Paper Sheets Made from Eucalyptus camaldulensis and Meryta sinclairii Wood Branches. Materials 2020, 13, 1292. [CrossRef] [PubMed]

56. Salem, M.Z.M.; Zidan, Y.E.; El Hadidi, N.M.; Mansour, M.M.; Abo Elgat, W.A.A. Evaluation of usage three natural extracts applied to three commercial wood species against five common molds. Int. Biodeterior. Biodegrad. 2016, 110, 206-226. [CrossRef]

57. Taha, A.S.; Abo Elgat, W.A.A.; Salem, M.Z.M.; Ali, H.M.; Fares, Y.G.; Elshikh, M.S. Impact of some plant source additives on enhancing the properties and antifungal activities of pulp made from Linen fibers. BioResources 2019, 14, 6025-6046.

58. Miklečić, J.; Španić, N.; Jirouš-Rajković, V. Wood color changes by ammonia fuming. BioResources 2012, 7, 3767-3778.

59. Essa, A.M.; Khallaf, M.K. Biological nanosilver particles for the protection of archaeological stones against microbial colonization. Int. Biodeterior. Biodegrad. 2014, 94, 31-37. [CrossRef]

60. Mansour, M.M.A.; Abdel-Megeed, A.; Nasser, R.A.; Salem, M.Z.M. Comparative Evaluation of Some Woody Tree Methanolic Extracts and Paraloid B-72 against Phytopathogenic Mold Fungi Alternaria tenuissima and Fusarium culmorum. BioResources 2015, 10, 2570-2584. [CrossRef]

61. Mansour, M.M.A.; Nasser, R.A.; Salem, M.Z.M.; Ali, H.M.; Hatamleh, A. Study of Mold Invasion on the Surface of Wood/Polypropylene Composites Produced from Aqueous Pretreated Wood Particles, Part 2: Juniperus procera Wood-Branch. BioResources 2017, 12, 4187-4201. [CrossRef]

62. Mansour, M.M.; Salem, M.Z.M. Evaluation of wood treated with some natural extracts and Paraloid B-72 against the fungus Trichoderma harzianum: Wood elemental composition, in-vitro and application evidence. Int. Biodeterior. Biodegrad. 2015, 100, 62-69. [CrossRef]

63. Nasser, R.; Mansour, M.M.A.; Salem, M.Z.M.; Ali, H.M.; Aref, I.M. Mold Invasion on the Surface of Wood/Polypropylene Composites Produced from Aqueous Pretreated Wood Particles, Part 1: Date Palm Midrib. BioResources 2017, 12. [CrossRef]

64. The Statistical Analysis System (SAS). Users Guide: Statistics (Release 8.02); SAS Institute Inc.: Cary, NC, USA, 2001.

65. Naumann, A.; Sudhakar, P.; Andrea, P. Fourier Transform Infrared Microscopy in Wood Analysis. In Wood Production, Wood Technology, and Biotechnological Impacts; Kües, U., Ed.; Universitätsverlag Göttingen, The Georg August University of Göttingen: Göttingen, Germany, 2007; p. 179. ISBN 978-3-940344-11-3.

66. Popescu, C.-M.; Popescu, M.-C.; Singurel, G.; Vasile, C.; Argyropoulos, D.; Willför, S. Spectral Characterization of Eucalyptus Wood. Appl. Spectrosc. 2007, 61, 1168-1177. [CrossRef] [PubMed]

67. Báder, M.; Németh, R.; Sandak, J.; Sandak, A. FTIR analysis of chemical changes in wood induced by steaming and longitudinal compression. Cellulose 2020, 27, 6811-6829. [CrossRef]

68. Nuopponen, M. FT-IR and UV Raman Spectroscopic Studies on Thermal Modification of Scots Pine Wood and Its Extractable Compounds; Series A, 23; Laboratory of Forest Products Chemistry, Helsinki University of Technology: Espoo, Finland, 2005.

69. Zhao, J.; Xiuwen, W.; Hu, J.; Liu, Q.; Shen, D.; Xiao, R. Thermal degradation of softwood lignin and hardwood lignin by TG-FTIR and Py-GC/MS. Polym. Degrad. Stab. 2014, 108, 133-138. [CrossRef]

70. Yassin, Z.; El Hadidi, N.N.; Mohamed, M.F. Examination and Analyses of a Wooden Face a The Museum Storage at The Faculty of Archaeology, Cairo University. Mediterr. Archaeol. Archaeom. 2016, 16, 1-11. [CrossRef]

71. Shi, J.; Xing, D.; Lia, J. FTIR Studies of the Changes in Wood Chemistry from Wood Forming Tissue under Inclined Treatment. Energy Procedia 2012, 16, 758-762. [CrossRef]

72. Bodirlau, R.; Teaca, C. Fourier transform infrared spectroscopy and thermal analysis of lignocellulose fillers treated with organic anhydrides. Rom. J. Phys. 2009, 54, 93-104.

73. Kavkler, K.; Demsar, A. Application of FTIR and Raman spectroscopy to qualitative analysis of structural changes in cellulosic fibres. Tekstilec 2012, 55, 19-31.

74. Müller, G.; Schöpper, C.; Vos, H.; Kharazipour, A.; Polle, A. FTIR-ATR spectroscopic analyses of changes in wood properties during particle-and fibreboard production of hard-and softwood trees. BioResources 2009, 4, 49-71. 
75. Tjeerdsma, B.F.; Militz, H. Chemical changes in hydrothermal treated wood: FTIR analysis of combined hydrothermal and dry heat-treated wood. Holz Roh Werkst. 2005, 63, 102-111. [CrossRef]

76. Chen, H.; Ferrari, C.; Angiuli, M.; Yao, J.; Raspi, C.; Bramanti, E. Qualitative and quantitative analysis of wood samples by Fourier transform infrared spectroscopy and multivariate analysis. Carbohydr. Polym. 2010, 82, 772-778. [CrossRef]

77. Bonifazi, G.; Calienno, L.; Capobianco, G.; Monaco, A.L.; Pelosi, C.; Picchio, R.; Serranti, S. Modeling color and chemical changes on normal and red heart beech wood by reflectance spectrophotometry, Fourier Transform Infrared spectroscopy and hyperspectral imaging. Polym. Degrad. Stab. 2015, 113, 10-21. [CrossRef]

78. Traoré, M.; Kaal, J.; Cortizas, A.M. Application of FTIR spectroscopy to the characterization of archeological wood. Spectrochim. Acta Part A Mol. Biomol. Spectrosc. 2016, 153, 63-70. [CrossRef]

79. Li, M.-Y.; Cheng, S.-C.; Li, D.; Wang, S.; Huang, A.-M.; Sun, S.-Q. Structural characterization of steam-heat treated Tectona grandis wood analyzed by FT-IR and 2D-IR correlation spectroscopy. Chin. Chem. Lett. 2015, 26, 221-225. [CrossRef]

80. Parida, C.; Dash, S.K.; Pradhan, C. FTIR and Raman Studies of Cellulose Fibers of Luffa cylindrica. Open J. Compos. Mater. 2014, 5, 5-10. [CrossRef]

81. Poletto, M.; Zattera, A.J.; Santana, R.M.C. Structural differences between wood species: Evidence from chemical composition, FTIR spectroscopy, and thermogravimetric analysis. J. Appl. Polym. Sci. 2012, 126, E337-E344. [CrossRef]

82. Traoré, M.; Kaal, J.; Cortizas, A.M. Differentiation between pine woods according to species and growing location using FTIR-ATR. Wood Sci. Technol. 2018, 52, 487-504. [CrossRef]

83. Gelbrich, J.; Mai, C.; Militz, H. Chemical changes in wood degraded by bacteria. Int. Biodeterior. Biodegrad. 2008, 61, 24-32. [CrossRef]

84. Sundqvist, B. Colour Changes and Acid Formation in Wood during Heating. Doctoral Thesis, Luleå Tekniska Universitet, Luleå, Sweden, 2004.

85. Bhuiyan, T.R.; Hirai, N.; Sobue, N. Changes of crystallinity in wood cellulose by heat treatment under dried and moist conditions. J. Wood Sci. 2000, 46, 431-436. [CrossRef]

86. Hakkou, M.; Pétrissans, M.; Zoulalian, A.; Gérardin, P. Investigation of wood wettability changes during heat treatment on the basis of chemical analysis. Polym. Degrad. Stab. 2005, 89, 1-5. [CrossRef]

87. Awoyemi, L.; Westermark, U. Effects of borate impregnation on the response of wood strength to heat treatment. Wood Sci. Technol. 2005, 39, 484-491. [CrossRef]

88. Beech, I.B.; Gaylarde, C. Recent advances in the study of biocorrosion: An overview. Rev. Microbiol. 1999, 30, 117-190. [CrossRef]

89. Ecaza, M.; Kronstad, J.W. Shared and distinct mechanisms of iron acquisition by bacterial and fungal pathogens of humans. Front. Cell. Infect. Microbiol. 2013, 3, 80. [CrossRef]

90. Gerwien, F.; Safyan, A.; Wisgott, S.; Brunke, S.; Kasper, L.; Hube, B. The Fungal Pathogen Candida glabrata Does Not Depend on Surface Ferric Reductases for Iron Acquisition. Front. Microbiol. 2017, 8, 1055. [CrossRef] [PubMed]

91. Stanford, F.; Voigt, K. Iron Assimilation during Emerging Infections Caused by Opportunistic Fungi with emphasis on Mucorales and the Development of Antifungal Resistance. Genes 2020, 11, 1296. [CrossRef]

92. Lugauskas, A.; Demčenko, I.; Selskienè, A.; Pakštas, V.; Jaskelevičius, B.; Narkevičius, A.; Bučinskienè, D. Resistance of Chromated Zinc Coatings to the Impact of Microscopic Fungi. Mater. Sci. 2011, 17, 20-26. [CrossRef]

93. Charng, T.; Lansing, F. Review of corrosion causes and corrosion control in a technical facility. TDA Prog. Rep. 1982, 42, 145-156.

94. $\mathrm{Gu}, \mathrm{T}$. New Understandings of Biocorrosion Mechanisms and their Classifications. J. Microb. Biochem. Technol. 2012, 4, 4. [CrossRef] 